Spring 4-9-2021

\title{
Evidence-Based End-of-Life Comfort Care Guidelines
}

Myla Maranan

University of St. Augustine for Health Sciences, m.maranan@usa.edu

DOI: https://doi.org/10.46409/sr.RCRN7065

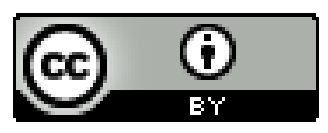

This work is licensed under a Creative Commons Attribution 4.0 License.

Follow this and additional works at: https://soar.usa.edu/scholprojects

Part of the Other Nursing Commons, and the Palliative Nursing Commons

\section{Recommended Citation}

Maranan, M. (2021). Evidence-Based End-of-Life Comfort Care Guidelines. [Doctoral project, University of St Augustine for Health Sciences]. SOAR @ USA: Student Scholarly Projects Collection. https://doi.org/ 10.46409/sr.RCRN7065

This Scholarly Project is brought to you for free and open access by the Student Research at SOAR @ USA. It has been accepted for inclusion in Student Scholarly Projects by an authorized administrator of SOAR @ USA. For more information, please contact soar@usa.edu, erobinson@usa.edu. 
EVIDENCE-BASED END-OF-LIFE COMFORT CARE GUIDELINES

\title{
Evidence-Based End-of-Life Comfort Care Guidelines
}

\author{
Myla Maranan, MSN, RN, CNML \\ School of Nursing, University of St. Augustine for Health Sciences
}

This Manuscript Partially Fulfills the Requirements

for the Doctor of Nursing Practice Program and is Approved by:

Sue Bingham, PhD, RN

Joseph Tadeo DNP, MPH, RN, CNS

April 9, 2021 


\title{
EVIDENCE-BASED END-OF-LIFE COMFORT CARE GUIDELINES
}

\begin{abstract}
Practice Problem: In the absence of end-of-life (EOL) comfort care guidelines, the nurses in a medical-surgical unit are apprehensive about caring for patients in their active stage of dying, which leads to abandoning the values of holistic and patient-centered care.

PICOT: The PICOT question that guided this project was: "How do acute care bedside nurses (P) who utilize the evidence-based comfort care guidelines (I) compare to not using the evidence-based guidelines (C) perceive their confidence in their capability to provide holistic and patient-centered care $(\mathrm{O})$ during the active onset of the patient's end-of-life stage $(\mathrm{T})$ ?"

Evidence: The literature indicated that accessible, evidence-based EOL comfort care guidelines could help nurses to enhance their confidence and skills to deliver holistic and patient-centered care at the bedside for actively dying patients.
\end{abstract}

Intervention: The nurses identified primary stressors for a dying patient within 24 hours of the patient deemed on EOL stage using a Patient Dignity Inventory Tool as an embedded part of EOL comfort care guidelines. The nurses initiated individualized plans of care based on the stressors identified, which upheld holistic and patient-centered EOL care concepts.

Outcome: Pre-and post-EOL intervention survey data attested that having accessible EOL comfort care guidelines was valuable for nurses in attaining more confidence in providing patient-centered and holistic care at the bedside for the actively dying patient.

Conclusion: Accessible, standardized, evidence-based EOL comfort care guidelines fostered the nurses' ability to provide care to patients who were actively dying, embracing the core concepts of holistic and patient-centered care. 


\section{EVIDENCE-BASED END-OF-LIFE COMFORT CARE GUIDELINES}

\section{End-of-Life Comfort Care Guidelines}

The provision of end-of-life (EOL) care is highly complex; therefore, nurses must receive support and vital resources to render comfort, quality care, and dignified death (Matzo \& Sherman, 2015). This project aimed to explore the in-depth creation of an evidence-based (EB) project promoting the use of comfort care guidelines (CCGs). This project's core mission was to ensure that nurses had leadership support and EB resources to improve their confidence in providing holistic and patient-centered care for dying patients requiring EOL care. Topics discussed in this paper covered the significance of the problem, PICOT question, quality improvement framework, change theory, evidence search results, project overview, project plan, evaluation, and practice recommendations.

\section{Significance of the Practice Problem}

There were about 2.7 million deaths in the United States in 2015, which was equivalent to $1 \%$ of the population (Aldridge \& Bradley, 2017, para. \# 1). Globally, the calculated mortality rate in 2018 was 7.7 deaths per 1,000 population (Aldridge \& Bradley, 2017, para. \# 3). In a similar year, the Centers for Disease Control and Prevention (CDC, 2018) reported that life expectancy was 78.6 years, with a fatality rate of 863.8 deaths per 100,000 population (para. \# 1). The above data revealed that many people were dying worldwide annually, and some of them suffered from failing to receive a quality of care during the EOL expedition (Aldridge \& Bradley, 2017).

Raijmakers et al. (2012) affirmed decedent's experiences of living through grave sickness differed considerably. Ideally, dying should be an authentic experience for individuals, and they should do so in peace and comfort (Aldridge \& Bradley, 2017). However, due to a lack of EB clinical practice guidelines, EOL care of patients with multiple comorbidities was challenging 


\section{EVIDENCE-BASED END-OF-LIFE COMFORT CARE GUIDELINES}

for healthcare providers to manage (Matzo \& Sherman, 2015). Consequently, not having EB clinical practice guidelines could result in adverse patient outcomes, such as patient suffering and failure to have a peaceful passing (American Nursing Association Center for Ethics and Human Rights, 2016).

In the United States, EOL care was considered resource-intensive, costly, and not focused on the patient's needs and preferences (Matzo \& Sherman, 2015). Bekelman et al. (2016) revealed that hospital's expenditures in the latter thirty days of a patient's life varied globally. Canada's $\$ 10,273$ average per capita was the most expensive, and in the United States, a figure of $\$ 8,126$ was ranking next for being costly (para. \#3). No matter the patient's country of origin, Bekelman et al. (2016) documented many instances of disconnect between the patient's asserted choices for dying at home and their actual experience dying in the hospital.

According to the American Nurses Association (2017), nurses should provide humane and compassionate EOL care and collaborate with the interprofessional team to secure optimal symptom management and to assist the patient and family (as cited in Strech \& Schildmann, 2011). Nurses are bound to institute decision-making processes that exhibit basic physiologic sensibilities and patient preferences (Hermann \& Looney, 2011). However, setting care goals for patients may need bargaining on what care should be provided. During the EOL process, the nurse is forced to intervene in the patient, family members, and interdisciplinary team members' ethical conflicts. Legal implications can also affect the nurses' autonomous decision-making when managing patients' EOL care (Brodtkorb et al., 2017). Therefore, EOL care goal setting demands collaboration with experts in decision-making, such as ethics committees or other interprofessional team members (American Nursing Association Center for Ethics and Human Rights, 2016). 


\section{EVIDENCE-BASED END-OF-LIFE COMFORT CARE GUIDELINES}

\section{PICOT Question}

The PICOT question was: "How do acute care bedside nurses (P) who utilize the evidence-based comfort care guidelines (I) compare to not using the evidence-based guidelines

(C) perceive their confidence in their capability to provide holistic and patient-centered care $(\mathrm{O})$ during the active onset of the patient's end-of-life stage (T)?"

The project's target participants were bedside nurses in the acute care setting who provided comfort care measures for patients in the EOL domain. Often, the nurses who manage patients' treatment at EOL encounter inhibitions to providing optimal care. These encompass inadequate preparation for facilitating challenging conversations and experience to manage the patient's pain and suffering, including personal discomfort with death and dying. It combines with a lack of resources to guide the nurses during this profound aspect of nursing care specific to EOL (Caton, \& Klemm, 2006).

The nurses' ability to cope and improve the confidence in rendering EOL comfort care may depend on appropriate resources (Matzo \& Sherman, 2015). There is an emphasis on using EB EOL CCGs to support the nurses at the bedside (Benkelman et al., 2016). Essential reference materials and easy-access resources can guide nurses as they cultivate skills and increase their confidence in the aspect of EOL care. It is conceivable that practice guidelines contain those measures to manage a patient's symptoms or impairments resulting from the underlying altered body systems that involve complex nursing care and interventions (Matzo \& Sherman, 2015). In many facilities, caring for a terminal or dying patient is not the norm. Hence, this EB project aimed to support the nurses caring for terminally ill patients by providing them access to EB practice resources, empowering them to initiate holistic and patient-centered care with adequate confidence and resilience (Henry, 2020). 


\section{EVIDENCE-BASED END-OF-LIFE COMFORT CARE GUIDELINES}

\section{Evidence-Based Practice Framework and Change Theory}

The EB practice model, which guided the development and implementation of this EB project, was the Iowa Model of EBP. It was the framework for constructing, implementing, and evaluating the EOL CCGs project. It gave a step-by-step guidance on tackling a clinical issue and pairing it with precise EB interventions. Additionally, it promoted quality care, improved patient outcomes, and commended the merit of nurses seeking inquiries to enhance clinical practice by applying the latest evidence (Brown, 2014).

Employing this model examined the cause of the problem identified and then built a team supporting, developing, implementing, and evaluating the EB practice change project. The next step was to involve collecting relevant evidence and analyzing pertinent literature associated with the practice change. This facet of the Iowa Model was crucial to forming a rooted question utilizing the PICOT method. Once the analysis of the evidence was done, identifying the proposed change for adoption in practice was made. The next step was to initiate the change in practice through project implementation on the medical unit. After implementation, the final step was centered on evaluating the change project by monitoring and analyzing its outcomes (White \& Spruce, 2015).

The implementation of EOL care additionally applied Lewin's theory of change model and served as a blueprint for an effectively planned change strategy. The central idea was to assess the clinical problem, implement the identified EB CCGs, and evaluate the outcome. Lewin (1951) identified three phases in which the change agent must proceed before a planned change would become part of the system: unfreezing, movement, and refreezing. Lewin further suggested that people like feeling safe, comfortable, and in control of their environment. For 


\section{EVIDENCE-BASED END-OF-LIFE COMFORT CARE GUIDELINES}

change to occur, the balance of driving and restraining forces must be altered. The driving forces must be increased, or the restraining forces decreased (Batras \&Smith, 2016).

In the unfreezing stage, the change agent gathered data, met with stakeholders about providing EOL care on a medical-surgical (MS) unit, and accurately assessed the staffing, environmental, and educational needs for providing care. The staff's current practices were assessed, persuaded of the needed change, and leadership support was provided at staff meetings to address concerns. Also, various strategies were employed to strengthen the driving energies and subdue coercive forces. Unfreezing entailed recognizing the staff affected by this change, followed by mobilizing them to articulate concepts, and generated lists of any motivating and underlying forces that transformed the project. During the moving phase, the real change was unfolded. In this stage, implementation of the EB EOL CCGs occurred, and the aspired changes emerged. Once the sought change was achieved, it was crucial to maintain open communication. Refreezing was the final stage, and at this stage, appraisal and permanency of the change occurred. Therefore, consistent monitoring of the change practice's overall effectiveness was necessary (Schriner et al., 2010).

\section{Evidence Search Strategy}

Searching for evidence was essential to implementing desirable change in practice. The effectiveness of this process was apparent over the ability to procure scholarly resources that could provide a precise answer to appropriate questions and inquiries (Stillwell \& Scott, 2020). Striving to focus mainly on the EOL comfort care materials, the utilization of electronic citation databases was investigated using the University of St. Augustine's electronic resources databases. These databases were the CINAHL Complete, Joanna Briggs Institute EBP Database, PubMed, and the Wiley Online Library through the USA search engine. 


\section{EVIDENCE-BASED END-OF-LIFE COMFORT CARE GUIDELINES}

Search strategies employed were central to the keywords based on the PICOT question. The origins of the phrases or words utilized included end-of-life, comfort care, patient-centered, and holistic care guidelines. The articles' initial search constituted full text, abstract, subject headings, and filters. The inclusion criteria were publications related to EOL care in the acute care setting and the dying adult population's comfort care. In contrast, the exclusion criteria were the publications on EOL care of pediatrics and neonatal patients and any outpatient and longterm care settings. Three general limiters were applied, irrespective of the database that was accessed. These pertained to the period of the research article publications, English as the publication language, and academic peered review journals with full text. The additional deletion of articles was on the duplicate identity of title names and content from every database, which was purposely precluded for the analysis to beseech the search efficiency. Besides the above strategies, articles greater than ten years old were also rejected. Finally, the search strategy concluded, and relevant scholarly journal articles were reviewed and chosen.

\section{Evidence Search Results and Evaluation}

The EB search results and evaluation of the studies were instrumental to the EOL CCGs EB project's conceptual progression. By conducting the initial search and employing the four picked databases, 1,538 articles emerged. Subsequently, ten pieces of literature remained after thorough reviews, removing duplicates, and applying the inclusion and exclusion criteria using a PRISMA flow diagram (see Appendix A). Evaluating the evidence of all the chosen studies demanded the application of Melnyk's Hierarchy Levels of Evidence. Through this EB guiding principle, the levels of evidence were reviewed on their methodological quality of design, validity, and applicability to patient care. These rulings signified the ranking or strength of evidence recommendation (Melnyk \& Fineout-Overholt, 2019). 


\section{EVIDENCE-BASED END-OF-LIFE COMFORT CARE GUIDELINES}

Ten scholarly articles were appraised utilizing Melnyks's Hierarchy of Levels of Evidence, and six, which were qualitative studies and underpinned the Level VI strengths of evidence, were reviewed. Meanwhile, the two analyzed quantitative studies were randomized controlled trials (RCT) and quasi-experimental designs. The inherited strength of evidence for RCT replicated Level II and quasi-experimental research clenched Level III is revealed in Appendix B. The last two inquiries were systematic review studies, and their level of evidence was rated as Level V as shown in Appendix C. Incorporating a systematic review was imperative as it contributed evidence that detected the gaps in the targeted EOL project. It suited the dynamic strength for further exploration; including, the unnecessary duplication of study, which favored better clinical outcomes for patients and commanded EB clinical decisions (Davies, 2019). Nonetheless, the pertinent collected studies presented good quality evidence with consistent results. The studies manifested the integration of best evidence, clinicians' expertise, patient inclinations, and values; therefore, they were deemed binding and presumed to deliver quality patient outcomes (Melnyk \& Fineout-Overholt, 2019).

\section{Themes from the Evidence}

A synthesis of the ten scholarly literature was necessary to understand the PICOT question's essentials. The prevailing interest in these studies was to delineate crucial means of upholding strong support for the frontline nurses at the bedside in caring for patients who require EOL care. Similarly, all these articles highlighted the investigational works that identified the benefits of employing EB EOL initiatives when caring for dying patients in the acute care setting.

The evidence from the entire collection of research studies illustrated that all the researchers applied various scientific instruments and statistical data to defend and support their 


\section{EVIDENCE-BASED END-OF-LIFE COMFORT CARE GUIDELINES}

assertions. Accordingly, there was one attribute that stood out among their work, and it was a calling to improve the EOL quality of care (Beernaert et al., 2017; Im et al., 2019; Kisorio \& Langley, 2016; Noble et al., 2018; Price et al., 2017; Reid et al., 2015; Stacy et al., 2019; Xiao et al., 2018; Carvajal et al., 2019; Virdun et al., 2015). Improving the quality of EOL care was accomplished by recognizing that nurses needed resources and EB strategies to adequately care and assist the patient and their loved ones during this challenging milestone of human life. Furthermore, six of the scholarly articles revealed that it was significantly thought-provoking to integrate EOL care in the milieu of an acute care setting. Researchers contended that in this particular environment, the commitment of the nurses and other healthcare workers' efforts was to discharge patients successfully (Beernaert et al., 2017; Im et al., 2019; Kisorio \& Langley, 2016; Noble et al., 2018; Price et al., 2017; Reid et al., 2015). The two profound emerging themes that firmly stood out from the synthesis of all these scholarly articles were the necessity for reliable and valid EB EOL standardized care guidelines and the importance of effective communication and collaboration of care between the nurses, patients, and their families (Beernaert et al., 2017; Im et al., 2019; Kisorio \& Langley, 2016; Noble et al., 2018; Price et al., 2017; Reid et al., 2015; Stacy et al., 2019; Xiao et al., 2018; Carvajal et al.,2019; Virdun et al., 2015).

\section{EOL Standardized Care Guidelines}

Evidence-based EOL CCGs were a tangible chief element that was highly recommended and shown to support nurses in delivering holistic and patient-centered EOL care. These guidelines could be tailored to account for different components expected to assist in the effective execution of EOL care. Two studies recognized that EOL care guidelines' implementation carried a target intention to remedy the usual lack of communication among the 


\section{EVIDENCE-BASED END-OF-LIFE COMFORT CARE GUIDELINES}

dying person, their loved ones, and the involved healthcare professionals (Beernaert et al., 2017; Noble et al., 2018). Indeed, these teams of scholarly inquiries highlighted that the presence of established and structured EOL guidelines offered nurses a sense of empowerment. Having access to EB resources, nurses could render optimal EOL care. Through strong EOL guidelines, shifting the focus of care from a relatively conventional biomedical approach to a more individualized and holistic approach of care was palpable (Stacy et al., 2019; Virdun et al., 2015). Also, these guidelines were in accord with delivering systematic guidance on important priorities when caring for dying patients. As a result, this projects' groundwork extended personal comfort and reassurance to nurses because this satisfied their demands of having straightforward and structured EOL care (Noble et al., 2018; Reid et al., 2015; Stacy et al., 2019; Virdun et al., 2015). Beernaert et al. (2017) also echoed this conceptual view. The analytical findings of their study confirmed that streamlining practice by implementing an EOL CCG was essential to producing a positive impact on comfort and quality of care, symptom management, and satisfaction of patient's care needs.

\section{EOL Care Effective Communication and Collaboration}

The definitive care strategies that affected EOL comfort care principles concerned the realm of effective communication and collaboration on EOL care (Carvajal et al., 2019; Reid et al., 2015; Virdun et al., 2015). Many patients must have an individual receptor for listening and sensitivity to acknowledge what to expect in responding to their physical and emotional needs. Likewise, patients and their families had compelling demands for honest communication (Virdun et al., 2015). For the patient's family, open communication was an essential ingredient that had significant relevance and value (Carvajal et al., 2019). Xiao et al. (2018) found that the prospect of the EOL care system of the future should cover healthcare organizations at all levels, with 


\section{EVIDENCE-BASED END-OF-LIFE COMFORT CARE GUIDELINES}

established mechanisms of collaboration among patients and establishments. Also, they affirmed that nurses were adept at having the autonomy to intervene and collaborate care with the patient without any reservation through effective communication. At the same time, Im et al. (2019) captured the proposition on restored nurses' relationship with patients and caregivers through active communication and care collaboration. They stretched nurses to build a meaningful connection between the patient and their family members.

A consistent and reliable body of evidence supporting the need for EOL CCGs was cited from all elected articles. Strength recommendations stood for the collection of evidence at Level VI, according to Melnyk's Hierarchy Levels of Evidence (Appendix B). Eight out of the ten articles were qualitative; the gained evidence was consistent and promoted good-quality patientcentered outcomes (Melnyk \& Fineout-Overholt, 2019).

\section{Practice Recommendations}

The literature review substantiated the idea that the construction of EB EOL CCGs could satisfactorily support the frontline nurses administering holistic and patient-centered care when caring for actively dying patients. The evidence offered a robust foundational concept that reflected EOL guidelines as an indispensable part of nursing practice in an acute care setting. Practice change recommendations were driven by most of the studies, which fervently employed the qualitative methodology. Its core elements involved soliciting shared personal anecdotes focused on the patient and their families, including nurses. The descriptive qualitative studies reflected the in-depth understanding of EOL care challenging the contextual theme, which exhibited the delineation of its evidence through narrative and case studies (Colorafi \& Evans, 2016). These studies highlighted the significance of practice change at the bedside by materializing standardized EB EOL CCGs, which fostered consistency of care as an outcome of 


\section{EVIDENCE-BASED END-OF-LIFE COMFORT CARE GUIDELINES}

enhancing practice. The evidence indicated that it was imperative to collect positive responses on comfort and quality of care, symptom management, and fulfillment of patient's needs in the EOL domain with the accessibility of the EOL CCGs (Beernaert et al., 2017; Noble et al., 2018; Reid et al., 2015; Carvajal et al., 2019; Virdun et al., 2015). The remarkable consistency of data gathering was exhibited by the cascading principle of concluding every study once data saturation was reached, which served as the decisive criterion for any qualitative inquiries (Colorafi \& Evans, 2016). The PICOT question was elucidated over the nurses' professed recognition around EOL guidelines' eminence impact by employing the predominant evidence. The EOL guidelines supported the nurses' advocacy of upholding the merit of excellent EOL comfort care in a holistic and patient-centered fashion. Nonetheless, generating standardized EOL CCGs was a compelling engine for the movement of EB practice change at the bedside (Beernaert et al., 2017; Noble et al., 2018).

\section{Project Setting}

The EB project's setting was situated at one of the country's largest comprehensive medical rehabilitation centers, which provides services to a wide range of individuals with catastrophic illnesses and injuries. The facility has an inpatient volume of 175 beds of medicalsurgical and rehabilitation units, including 12 beds exclusive for intensive care operations. As a prime rehabilitation hospital, the organization continues to pioneer creative and innovative services that promote recovery, community integration, and independence for clients recovering from or living with a physical disability (dhs.lacounty.gov).

\section{Organizational Structure}

The organizational structure fits the description of a mechanistic structure. The institution builds a clear vertical hierarchy for authority, accountability, and communication framework that 


\section{EVIDENCE-BASED END-OF-LIFE COMFORT CARE GUIDELINES}

specified adherence to the chain of command. This approach emphasizes vertical coordination among the departments. All the stakeholders have a clear definition of their specific jobs, and upper management acts as the primary decision-maker (dhs.lacounty.gov).

The organization's mission is to restore health, rebuild, and revitalize hope for persons with a life-changing illness, injury, or disability. The vision is acknowledged as a worldwide groundbreaker in rehabilitation medicine and clinical research. The emphasis is placed on the culture of patient-centered care. Each employee is expected to be respectful and responsive to individual patient preferences, needs, and values and practice compassion, empathy, warmth, kindness, active listening, respect, and dignity. With the above attributes, open communication with the patient and their support systems, respecting patient choice in their health care decision, and collaborating with patients and their support system are also intensely rooted in the organization's ordinary clinical practice (Rancho Mission and Vision, 2014).

The need to have robust EOL CCGs was noted and recommended by the nursing staff in one of the MS units. Consequently, the area has been designated to accommodate EOL patients throughout the facility. The compelling need for the organizational assessment to discern the institution's transformational readiness was evident. Checklist to Assess Organizational Readiness' (CARI) framework was a crucial assessment tool that tested its readiness to implement an EB initiative. The formation of transparent data depicted each project team member's factual position on the targeted project (Barwicjk, 2011). The synthesized aggregate data, with the measurement of the organization's cultural profile, formed a theme. It reflected on the outstanding senior leadership support in fulfilling the aim of the project to galvanize change. It was associated with higher demands for the cultivation of staff's new knowledge and skills necessary to solidify project readiness. 


\section{EVIDENCE-BASED END-OF-LIFE COMFORT CARE GUIDELINES}

The utilization of EB practice to improve patient outcomes was paramount to nursing practice, and the MS nurses accepted this project. Therefore, the frontline staff unified to having unit champions to facilitate buy-in using the EOL CCGs throughout the unit. It was a decisive action to make this project actively operative and efficient. Additionally, to ensure the team's engagement and sustainability, identifying the supervising staff nurses (SSNs) and unit charge nurse designees, in the absence of the SSN, as vital frontline leaders of this initiative was essential. These individuals reinforced staff compliance with the utilization of the guidelines in their daily nursing practice. The unit leaders' dynamic support, such as the nurse manager, physicians, and the entire interdisciplinary team, was compelling to the project's success and all the frontline nurses' permanent commitment. It was palpable through their consistent usage of the guidelines as a routine part of the EOL bedside clinical practice. The project lead gained support from all the stakeholders by fostering open communication and providing weekly feedback to the interdisciplinary team. It included recognizing the nurse's constant collaboration with the patient and their support systems and respected patient choice in their health care decision.

\section{SWOT Analysis}

SWOT analysis is a reliable measure for any project analysis considering it is simple, has clear logic, and appropriately applicable in any industry (Shahmoradi et al., 2017). The application of SWOT analysis brought the organizational assessment and unveiled its strengths on outstanding leadership support, strong interprofessional collaboration, organizational readiness, and resiliency to change. Conversely, the organization's exhibited weaknesses were that some staff showed resistance to change. Also, they were accustomed to the inconsistent and non-standardized practice, including, without enough resources and skilled subject matter experts 


\section{EVIDENCE-BASED END-OF-LIFE COMFORT CARE GUIDELINES}

on EOL care. Opportunities pointed to improve staff, patients, and families' satisfaction and transform the staff's outlook on the EOL comfort care once they learned new strategies to enhance EOL clinical practice. The threats would have been its potential impact on reimbursement, patient diverse cultural and ethical perspectives, and external organizational priorities due to the COVID-19 pandemic (see Appendix D).

\section{Project Overview}

The goal of generating EB CCGs was to facilitate dependable and swift comfort care resources for the nurses to use in the MS unit in providing holistic and patient-centered care for an EOL patient. The EOL CCGs' development entailed incorporating the EB Patient Dignity Inventory tool's (PDI) (see Appendix E) conceptual elements and framework. The EOL guidelines' construction also involved the project lead's consultation and collaboration with the certified hospice and palliative care nurse, the facility's EOL subject matter expert. Additionally, it was imperative to seek input from the interdisciplinary team and gather all searched evidence to finalize EOL guidelines. The execution of these efforts served as the project lead's fundamental strategies to ensure that the guidelines were wholly developed and ready for use before its target implementation.

The PDI tool is a questionnaire comprised of 25 questions/indicators. The questions were simple, open-ended, and straightforward. These questions were designed to identify essential stressors when planning and delivering care for an actively dying patient (dignityincare.ca). The nurse completed this PDI tool questionnaire within 24 hours of identifying the EOL patient by the interdisciplinary team. The nurse placed the completed PDI tool inside each patient's chart and used it as a communication reference for the interdisciplinary team. This action helped interdisciplinary team members quickly identify EOL care problems and guided them for 


\section{EVIDENCE-BASED END-OF-LIFE COMFORT CARE GUIDELINES}

appropriate interventions. For each standard question from the PDI tool, the patient indicated his/her level of concern on a five-point scale, with 1 meaning "not a problem" and 5 indicating "overwhelming problem" (dignityincare.ca). The nurse initiated the patient's appropriate care plan if the patient's score on the problem indicators was three and above.

Embedded in the attached guidelines were comprehensive EB comfort care interventions centered on physical, psychosocial, emotional, and spiritual domains, which helped alleviate the dying patient's distress. Through collaborating with the patient and the interdisciplinary team, the licensed nurses at the bedside were able to identify the patients' suitable plan of care according to problem indicators in the guidelines. This identified plan of care was fully integrated into the overall daily clinical therapeutic interventions rendered to patients. The utilization of the established EOL CCGs promoted the nurse's autonomy and decision-making, including influencing the nurse's confidence to exercise active and open communication and instituted effective care collaboration.

\section{Project Mission and Vision}

The project's core vision was for bedside nurses to provide care with adequate confidence and be reliable in performing innovative EOL care measures. Transforming the quality of care in the EOL domain by creating standardized EOL CCGs, the project's mission and vision strongly harmonized with the organization's mission and vision; thus, allowing the patient to die in comfort and dignity.

\section{Project Objectives}

\section{Short-term}

The first objective was to examine the latest evidence specific to EOL comfort care for a dying patient two months before the project implementation. The next was developing the EB 


\section{EVIDENCE-BASED END-OF-LIFE COMFORT CARE GUIDELINES}

EOL CCGs based on the gathered evidence, consulting, and collaborating with the certified hospice and palliative care nurse, who served as subject matter expert on EOL care in the facility. Seeking input from the interdisciplinary team about the constructed EOL guidelines a month before initiating the selected unit's project implementation was the other focused objective. It was followed by performing pre-implementation surveys to learn the nurse's perception of EOL care practices at the bedside, without a guideline, a week before the project started. Upon completion of such surveys, the next goal was to facilitate the staff training and competency on the EOL CCGs within the same week.

\section{Long-term}

The first aim was to sustain the nurse's capability to utilize the newly formed EB EOL CCGs at the bedside by incorporating them into the licensed nurses' unit-based orientation program once implemented in the MS unit. The second target objective was to expand the utilization of the constructed EB EOL CCGs in the designated organization after two months of project completion in the MS unit.

\section{Risk}

The project's risk and unintended consequences included the nurses' inability to adapt and/or a lack of compliance to apply the set measures from the new EOL CCGs. There were specific actions that were done to mitigate these identified risks. First, the staff was empowered to contribute input in the whole process and ascertained how the new EB EOL CCGs could positively influence their ability to render patient-centered and holistic care to the actively dying patients. Next, a continued open communication and feedback was initiated for the staff, including commending and praising them for adhering to the EOL CCGs utilization (Xiao et al., 2018). The nurses would be informed that their compliance for the EOL guidelines' employment 


\section{EVIDENCE-BASED END-OF-LIFE COMFORT CARE GUIDELINES}

would magnify their ability to foster EOL comfort care's optimum consistency as an outcome (Stacy et al., 2019).

\section{Project Plan}

The Iowa Model of EBP was the framework utilized to guide the development and implementation of this project. This model's employment started by examining the cause of the problem identified. The lack of EOL comfort care resources for the nurses at the bedside was recognized as a priority problem and started once the target unit was designated to care for the EOL patients throughout the facility. This clinical operation change gave the nurses in the MS unit some apprehensions since taking care of the actively dying patients was not part of their daily work routine. The unit nurse manager and the staff presented the need to have standardized EB EOL guidelines to support them in caring for these patients in the unit.

The next step entailed forming the EOL comfort care team. The team consisted of the DNP student as the project lead, unit nurse manager, supervising staff nurses, unit educator, certified palliative care nurse, patient advocate, staff nurses, physicians, physical and occupational therapists, psychologists, and dieticians. Once the project team's construction was completed, the next crucial step was to assemble relevant evidence and related literature based on the formed PICOT question.

The Iowa model's succeeding step was reviewing and synthesizing the searched evidence. The process to evaluate the evidence of all the chosen literature used the application of Melnyk's Hierarchy Levels of Evidence, in which the appraisal of the ten unique articles was executed. These articles prospectively manifested the integration of best evidence, clinicians' expertise, and patient's inclinations and values. The evaluated searched evidence on the EOL care was 


\section{EVIDENCE-BASED END-OF-LIFE COMFORT CARE GUIDELINES}

presented and discussed with the interdisciplinary team. The whole team agreed that enough reliable evidence strengthened and positively supported the project's implementation.

Moving to the implementation step involved executing the project in the MS unit. However, before the project could start, a pre-implementation survey of the nurses was conducted to learn their perceived confidence and capability to provide holistic and patientcentered care to a patient on EOL without EOL CCGs. The survey utilized the "Nurse's Perception of End-of-Life Comfort Care" as the collection tool is illustrated in Appendix F. Identifying supervising staff nurses (SSNs) as unit champions was the next step. The project implementation unit had two SSNs, and each of them were assigned to each shift as the designated lead for the delivery of nursing care at the bedside. They were experienced nurses, well respected by the entire interdisciplinary team, and highly motivated frontline nursing leaders. As unit champions, their primary role was to actively collaborate and continuously communicate with the project lead to facilitate nurses' buy-in and the entire interdisciplinary team members, which ensured that the team would remain engaged so that the project would stay sustainable. The unit champions received the appropriate training of the completed lesson plan shown in Appendix G. As unit champions, they were also required to review the organization's policy on HIPAA and preserve patient confidentiality, including the processes involved in collecting the pre-and post-project implementation data. After training completion, they also took the written test to validate their knowledge and competency on the EOL CCGs, as showed in Appendix H. As unit champions, they had to receive a score of $80 \%$ or above to be deemed competent and capable of applying the EB CCGs at the bedside.

Another intervention involved in implementing the project was for the nursing staff's training on the new EB EOL CCGs shown in Appendix I. The project lead collaborated with the 


\section{EVIDENCE-BASED END-OF-LIFE COMFORT CARE GUIDELINES}

unit nursing educator and nurse manager for the efficiency of training to achieve greater numbers of licensed staff attending the training. The lesson plan for the team in-service was accomplished, which offered a general outline of the teaching goals and learning objectives. The in-service's primary focus was on the staff's knowledge and skill procurement to apply the EOL CCGs at the bedside. During the in-service, the lesson plan's materials were presented using the generated PowerPoint showcased in Appendix J. Flyers presented in Appendix K were posted on the unit communication board a week before the training to announce and communicate the target training as planned. During training, rosters were utilized, as seen in Appendix L, to identify the number of registered nurses (RNs) who successfully received the training on the new EOL comfort care guidelines. After the in-service, the same brief written test above was given to the participants to determine if they understood the entire process of how to utilize and apply the EOL CCGs at the bedside. The nurses had to obtain a passing score of $80 \%$ or above to be deemed competent to use and incorporate the EOL guidelines into their daily clinical practice.

The following step was the evaluation of the project execution. It was fulfilled by performing a retrospective patient medical records review by the project lead and the unit champions. The purpose was to evaluate the nurses' utilization and adherence to the established EOL CCGs by utilizing the "EOL Comfort Care Guidelines Audit Tool" located in Appendix M. Additionally, post-implementation surveys were completed by the trained nurses employing the "Nurse's Perception of End-of-Life Comfort Care" audit tool exhibited in Appendix N.

Comparing the pre-and post-implementation survey data was made by exploiting the Chi-square test statistical tool.

After the EB EOL comfort care project's completion, the whole team envisioned that nurses' perceived confidence would increase and their ability to swiftly provide holistic and 


\section{EVIDENCE-BASED END-OF-LIFE COMFORT CARE GUIDELINES}

patient-centered EOL care would be the norm. Yielded from the nurses' consistent application of EOL CCGs would be the origin of the fundamental practice change of EOL care in the MS unit. The execution of the project's objectives served as valuable means for defining the necessary corrective measures, including the project's full acceptance and sustainability. Following the project's successful implementation, the next critical step was to review the results, disseminate the outcome, and expand the facility's newly recognized EB EOL CCGs utilization.

\section{Barriers}

There were significant impediments identified during the implementation phase of the EOL project. The first was having only four patients who participated in the project's implementation. The next was securing only $50 \%$ of the nurses completing and submitting the post-implementation survey two weeks after the project completion. The causative circumstance for gaining lower RNs' participation in meeting the post-project implementation surveys was the unforeseen incidence of patients' surge of admission in the project site related to the COVID-19 pandemic. This pandemic prompted the demand for some of the MS nurses to float and or temporarily be assigned to the progressive care unit to meet the staffing needs of much sicker and higher acuity patients. Also, there had been higher occurrences of nurses calling in sick linked to COVID-19 during the entire eight-week duration of the project implementation.

\section{Gantt chart}

The Gantt chart's utilization was crucial to plan, schedule, and note the entire project's critical tasks and target milestones. This management tool illustrated project progression and development, beginning from planning to implementation and outcome evaluation (see Appendix O). 


\section{EVIDENCE-BASED END-OF-LIFE COMFORT CARE GUIDELINES}

\section{Budget}

The projects' financial costs were mainly associated with approximating the staff's nonproductive hours involved in the project. Most of the non-productive hours were used for project meetings. There were considerable expenses due to the staff's allocated time attending the training of the EOL guidelines before its implementation. The complete list of the disciplines and breakdown of the related expenses is available in Appendix P.

\section{Evaluation Results}

The target participants were 40 RNs in the acute MS setting. The project inclusion criteria were RNs currently working in the MS unit with or without the experience of delivering EOL comfort care. Exclusion criteria comprised of any RNs not assigned to the project target site. The surveys and audit tools used in this project did not include any patient and nurse identifying information. Instead, a production of a unique identifier for every participant was developed. This mechanism was done during the data solicitation from patient health records and staff surveys to safeguard confidentiality. Data collection, interpretation of the data, and dissemination of findings were completed. Also, the team observed ethical courtesy to preserve human rights during the project initiation. The University of St. Augustine's Evidence-Based Practice Review Committee (EPRC) and designated project site reviewed and authorized the project proposal.

\section{Patient Dignity Inventory Tool}

The structure of the EOL CCGs included the integration of conceptual elements of the EB PDI tool. Permission to utilize this tool was attained through its author's approval via email, which is disclosed in Appendix Q. Chochinov et al. (2008) tested the PDI's validity by applying the tool on 253 patients accepting palliative care, which confirmed that PDI was a valid and 


\section{EVIDENCE-BASED END-OF-LIFE COMFORT CARE GUIDELINES}

reliable innovative tool that could help clinicians find the EOL patient's dignity-associated distress.

\section{Data Collection, Evaluation Designs, and Data Analysis}

Before the project began, the "Nurse's Perception of End-of-Life Comfort Care" survey was administered to thirty-four RNs to assess the nurses' perceived confidence in providing EOL holistic and patient-centered care without EOL CCGs. Also, 20 RNs completed postimplementation survey. During the data analysis and evaluation, SPSS V27 was used to compare the pre-and post-implementation nurses' survey results. The Chi-square test of association was employed to determine if the nominal variables were significantly associated.

The variables under consideration were implementation (yes or no), adequate level of confidence (yes or no), adequate resources (yes or no), and benefit (yes or no). Additionally, the demographic variables of education level and years of experience as an $\mathrm{RN}$ were compared between the two groups to determine if the proportions of participants' demographics were similar. It was accomplished by performing the Chi-Square goodness of fit test. RN years of experience for each group were measured. The proportions of years of experience seemed to be similar (Table 1). The results were not significant, indicating that the distribution of years of RN experience was similar between pre-and post-implementation groups, $\chi 2(2)=0.254, p=.881$. Moreover, the education levels' distributions were similar between the two groups (Table 1). The chi-square test results were non-significant, showing that the distributions of education levels between the two groups were not significantly different, $\chi 2(3)=0.819, p=.845$. 


\section{EVIDENCE-BASED END-OF-LIFE COMFORT CARE GUIDELINES}

Table 1

$R N$ Years of Experience and Education Level

\begin{tabular}{llcc}
\hline Intervention & & Frequency & Percent \\
\hline \multirow{3}{*}{ No } & $1-5$ yrs. & 6 & 17.6 \\
& $5-10$ yrs. & 18 & 52.9 \\
& $>10$ yrs. & 10 & 29.4 \\
& Total & 34 & 100.0 \\
& $1-5$ yrs. & 3 & 15.0 \\
\multirow{3}{*}{ Yes } & $5-10$ yrs. & 12 & 60.0 \\
& $>10$ yrs. & 5 & 25.0 \\
& Total & 20 & 100.0 \\
\hline \multirow{4}{*}{ No } & ADN & 13 & 38.2 \\
& BSN & 17 & 50.0 \\
& MSN & 3 & 8.8 \\
& DNP & 1 & 2.9 \\
\multirow{4}{*}{ Yes } & ADN & 6 & 30.0 \\
& BSN & 10 & 50.0 \\
& MSN & 3 & 15.0 \\
& DNP & 1 & 5.0 \\
\hline
\end{tabular}

The PDI tool was designed to identify essential stressors when planning and delivering care for a patient on the verge of dying. Baseline measures of four actively dying patients were collected during the time of project implementation. Responses ranged from 1 "not a problem" to 5 "an overwhelming problem." The item with the highest mean response pertains to the element "Experiencing physically distressing symptoms" $(M=3.25, S D=0.50)$. The remaining items were either a slight problem or not a problem. More details of the PDI responses from the four actively dying patients are exhibited in Appendix R.

To conclude, if the implementation (yes or no) of the EB EOL CCGs was associated with the facility's perceived adequacy to provide EOL care (yes or no), the Chi-square test of association was conducted. All participants stated that there were adequate resources in place within the post-implementation group (Table 2). 


\section{EVIDENCE-BASED END-OF-LIFE COMFORT CARE GUIDELINES}

Table 2

Adequate Resources

\begin{tabular}{llcc}
\hline Intervention & & Frequency & Percent \\
\hline \multirow{3}{*}{ No } & No & 8 & 23.5 \\
& Yes & 26 & 76.5 \\
Yes & Total & 34 & 100.0 \\
\hline
\end{tabular}

The chi-square test results indicated an association between the intervention and perceived adequacy of the facility to provide EOL, $\chi 2(1)=5.524, p=.019$.

A Chi-square test was performed to determine if the intervention (yes or no) was associated with perceived confidence (yes or no). Post-implementation data showed $70 \%$ of the RN participants felt confident in providing holistic and patient-centered EOL care compared to $56 \%$ of the pre-implementation group (Table 3). These differences, however, were not statistically significant as denoted by a non-significant Chi-square test, $\chi 2(1)=1.056, p=.304$.

Table 3

Perceived Confidence by Intervention

\begin{tabular}{llcc}
\hline Intervention & Confidence & Frequency & Percent \\
\hline \multirow{3}{*}{ No } & No & 15 & 44.1 \\
& Yes & 19 & 55.9 \\
& Total & 34 & 100.0 \\
\multirow{3}{*}{ Yes } & No & 6 & 30.0 \\
& Yes & 14 & 70.0 \\
& Total & 20 & 100.0 \\
\hline
\end{tabular}

Lastly, the association between the intervention and whether or not RNs could benefit from EOL CCGs was assessed. In both groups, all agreed that RNs could benefit from having the EOL CCGs in providing holistic and patient-centered care to the patient who is on the verge of 


\section{EVIDENCE-BASED END-OF-LIFE COMFORT CARE GUIDELINES}

dying; thus, no correlations could be calculated as every RN participant in both pre-and postimplementation group agreed.

\section{Impact}

The EOL CCGs' significant influence in nursing clinical practice at the bedside is encouraging from the MS nurses' perspective. It carries a wide range of referential information, which transforms and enriches nurses' approaches and techniques of caring for patients who are actively dying. The literature affirmed that essential reference information, materials, and quickly available resources could guide nurses as they cultivate proficiency and confidence in the aspect of EOL care (Matzo \& Sherman, 2015). Since the nurses who participated in this project have learned to efficiently access and utilize the EOL guidelines, they have earned an indepth interest in embracing the fundamental concept of holistic and patient-centered care. It was apparent as the staff eagerly exercised their profound commitment to addressing the patients' individualized demands around their physical, psychological, social, and spiritual needs during their active stage of dying.

Additionally, the EB information and knowledge that stemmed from these guidelines served as the core proposition that helped the nurses feel comfortable and confident caring for the dying patients. As nurses adhered to the established EOL CCGs' employment, the procurement of patient's optimum quality care was vastly achieved. Barriers to unsuitable utilization of treatment, miscommunication among the team, and inadequate management of patients' EOL symptoms were addressed. Having the EOL guidelines limited the possibility of delivering substandard nursing care and fragmented clinical services. Instead, it transmitted a robust structure and promoted an integrated and reliable team-based approach to managing dying patients through solid collaboration and therapeutic communication between interdisciplinary 


\section{EVIDENCE-BASED END-OF-LIFE COMFORT CARE GUIDELINES}

teams. It included establishing a trusting relationship and fostering shared decision-making with the patient and family.

\section{Limitations}

There were several limitations, which attributed to this EB EOL project. First, the project participants' sample size was small, since it was limited solely to RNs in a 25 bed MS unit. Second, the guidelines restricted application to only four recognized actively dying patients during the eight weeks of the project implementation. Third was related to the imposed target of instant post-implementation turn-around time of two weeks for the RNs to submit their surveys. However, the RNs were confronted with multiple competing priorities due to radical patient surge brought on by the COVID-19 pandemic. Due to these trying times, a relatively low number of post- implementation RNs' surveys were solicited $(n=20)$, which was less than expected.

\section{Sustainability}

Through this project's notable positive impact on the nurses and patients involved, the team strongly agreed that sustaining the EB EOL CCGs' adoption would be inevitably paramount. The identified vital measure for its sustainability plans would be to include the EOL guidelines in the staff's annual educational training and establish standard expectations for nurses to incorporate these EB guideline interventions into their daily nursing practice. Hence, the team would need to introduce and implement the guidelines in the entire facility for it to become part of the routine EOL care measures as the next step. Also, to seek continuous provisional support of the key nursing leadership, allowing the palliative nurse to champion EOL CCGs permanence application at the bedside and the guidelines be viewed as a useful nursing tool. 


\section{EVIDENCE-BASED END-OF-LIFE COMFORT CARE GUIDELINES}

\section{Dissemination Plan}

The project's results will be presented to the institution where the project unfolded over the MS interdisciplinary collaborative meeting. Frontline nurses headed this monthly gettogether assembly along with the MS clinical director, unit nurse manager, case manager, social worker, physical and occupational therapists, physicians, dietitian, and unit support staff. A PowerPoint presentation will be used to describe the project's findings. The dissemination of this project in the facility will also be expanded to the Operation Council meeting, with nursing leadership's attendance. Locally, sharing it with the other three hospitals within the network by participating in the yearly Department of Health Services Safety Conference will be the next stride. Regionally, offering this project to a Magnet conference will be fitting. Embarking on the Magnet journey, the interdisciplinary team considers that it will be a brilliant addition since the conference attendees are RNs, and this forum focuses on cultivating the nurse's continuous professional development (Walker et al., 2010).

Publication of this EOL guideline in the MEDSURG Nursing Journal will be the DNP student's future yearning. This project is driven by inclined practice change in an acute MS setting. Aiming to be part of this journal is due to its unequivocal periodical, which has been the premier origin of EB practice in the MS nursing society. It is also a medium for the Academy of Medical-Surgical Nurses to cede its quest to advance the care of ailing patients and their families (Research \& Markets, 2011).

\section{Conclusion}

This project captures the intricate process of forming and administering the EB EOL CCGs in the acute care setting. EOL is an integral part of human life; therefore, any individual who is actively dying should experience optimal quality comfort care. Appraising and 


\section{EVIDENCE-BASED END-OF-LIFE COMFORT CARE GUIDELINES}

synthesizing literature was pivotal for procuring essential evidence to attest that accessible EB EOL CCGs could benefit the nurses and patients. The actuality of caring for the dying patient is not a standard component of the nurse's daily clinical practice. Thus, this project evaluated the significance of EOL CCGs' position in enhancing the nurses' confidence to render holistic and patient-centered EOL care. After eight weeks of project implementation, it was evident that the EOL CCGs undoubtedly helped improve the nurses' level of confidence in providing holistic and patient-centered EOL care. Besides, all the nurses who participated in this EB project

acknowledged that EOL CCGs were beneficial to their daily clinical practice. Most importantly, this project contributed to rendering excellent patient care delivery in the EOL domain, which aligns with the organization's mission. 


\section{EVIDENCE-BASED END-OF-LIFE COMFORT CARE GUIDELINES}

\section{References}

Aldridge, M. D., \& Bradley, E. H. (2017). Epidemiology and patterns of care at the end of life: Rising complexity shifts in care patterns and sites of death. Health Affairs, 36(7), 11751183. http://dx.doi.org/10.1377/hlthaff.2017.0182

American Nursing Association Center for Ethics and Human Rights. (2016). Nurses' roles and responsibilities in providing care and support at the end of life. https://www.nursingworld.org/ 4af078/globalassets/docs/ana/ethics/endoflifepositionstatement.pdf

Barwicjk, M.A. (2011). Checklist to assess organizational readiness (CARI) for EIP implementation. http://www.effectiveservices.org/downloads/Checklist to Assess Orga nisational_Readiness_for_Implementation.pdf

Batras, D., Duff, C., \& Smith, B. J. (2016). Organizational change theory: Implications for health promotion practice. Health Promotion International, 31(1), 231241. https://doi.org/10.1093/heapro/dau098

Beernaert, K., Smets, T., Cohen, J., Verhofstede, R., Costantini, M., Eecloo, K., . . . Deliens, L. (2017). Improving comfort around dying in elderly people: A cluster randomized controlled trial. The Lancet, 390(10090), 125-134. http://dx.doi.org/10.1016/S0140$\underline{6736(17) 31265-5}$

Bekelman, J. E., Halpern, S. D., Blankart, C. R., Bynum, J. P., Cohen, J., Fowler, R., Kaasa, S., Kwietniewski, L., Melberg, H. O., Onwuteaka-Philipsen, B., Oosterveld-Vlug, M., Pring, A., Schreyögg, J., Ulrich, C. M., Verne, J., Wunsch, H., \& Emanuel, E. J. (2016). Comparison of site of death, health care utilization, and hospital expenditures for patients 


\section{EVIDENCE-BASED END-OF-LIFE COMFORT CARE GUIDELINES}

dying with cancer in 7 developed countries. JAMA, 315(3), 272-283. https://doi.org/10.1001/jama.2015.18603

Brodtkorb, K., Skisland, A. V., Slettebø, Å., \& Skaar, R. (2017). Preserving dignity in end-oflife nursing home care: Some ethical challenges. Nordic Journal of Nursing Research, 37(2), 78-84. http://dx.doi.org/10.1177/2057158516674836

Brown, C. G. (2014). The iowa model of evidence-based practice to promote quality care: An illustrated example in oncology nursing. Clinical Journal of Oncology Nursing, 18(2), 157-9. https://search.proquest.com/docview/1512448399?accountid=45853

Carvajal, A., Haraldsdottir, E., Kroll, T., McCormack, B., Errasti-Ibarrondo, B., \& Larkin, P. (2019). Barriers and facilitators perceived by registered nurses in providing personcentered care at the end of life. A scoping review. International Practice Development Journal, 9(2), 1-22. https://doi.org/10.19043/ipdj.92.008

Caton, A. P., \& Klemm, P. (2006). Introduction of novice oncology nurses to end-of-life care. Clinical Journal of Oncology Nursing, 10(5), 604-8. Retrieved from https://search.proquest.com/docview/222747919?accountid=45853

Chochinov, H. M., Hassard, T., McClement, S., Hack, T., Kristjanson, L. J., Harlos, M., Sinclair, S., \& Murray, A. (2008). The patient dignity Inventory: A novel way of measuring dignity-related distress in palliative care. Journal of Pain and Symptom Management, 36(6), 559-571. https://doi.org/10.1016/j.jpainsymman.2007.12.018.

Choi, M., Lee, J., Kim, S., Kim, D., \& Kim, H. (2012). Nurses' knowledge about end-of-life care: Where are we? The Journal of Continuing Education in Nursing, 43(8), 379-84. http://dx.doi.org/10.3928/00220124-20120615-35 


\section{EVIDENCE-BASED END-OF-LIFE COMFORT CARE GUIDELINES}

Colorafi, K. J., \& Evans, B. (2016). Qualitative descriptive methods in health science research. HERD: Health Environments Research \& Design Journal, 9(4), 16-25. http://dx.doi.org/10.1177/1937586715614171

Davies, A. (2019). Carrying out systematic literature reviews: an introduction. British Journal of Nursing, 28(15), 1008-1014. https://doi.org/10.12968/bjon.2019.28.15.1008

Death rate, crude. (n.d). https://data.worldbank.org/indicator/SP.DYN.CDRT.IN

Henry, B. (2020). End of life feeding: Ethical and legal considerations. Physiology \& Behavior, 217. https://doi.org/10.1016/j.physbeh.2020.112800

Hermann, C., \& Looney, S. W. (2011). Determinants of quality of life in patients near the end of life: A longitudinal perspective. Oncology Nursing Forum, 38(1), 23-31. https://search.proquest.com/docview/822930967?accountid=45853

Im, J., Mak, S., Upshur, R., Steinberg, L., \& Kuluski, K. (2019). "Whatever happens, happens" challenges of end-of-life communication from the perspective of older adults and family caregivers: A qualitative study. BMC Palliative Care, 18(1), 1-9. https://doi.org/10.1186/s12904-019-0493-7

Izumi, S., Nagae, H., Sakurai, C., \& Imamura, E. (2012). Defining end-of-life care from perspectives of nursing ethics. Nursing Ethics, 19(5), 608-618. http://dx.doi.org/10.1177/0969733011436205

Kisorio, L. C., \& Langley, G. C. (2016). Intensive care nurses' experiences of end-of-life care. Intensive \& Critical Care Nursing, 33, 30-38. http://dx.doi.org/10.1016/j.iccn.2015.11.002

Matzo, M. F., \& Sherman, W. D. (2015). Palliative Care Nursing: Quality Care to the End of Life: Vol. Fourth edition. Springer Publishing Company. 


\section{EVIDENCE-BASED END-OF-LIFE COMFORT CARE GUIDELINES}

Melnyk, B.M. \& Fineout-Overholt, E. (2019). Evidence-based practice in nursing \& healthcare: A guide to best practice (4th ed.) Philadelphia, PA: Wolters Kluwer/Lippincott Williams \&Wilkins.

Moher, D., Liberati, A., Tetzlaff, J., Altman, D.G., \&The PRISMA Group. (2009). Preferred reporting items for systematic reviews and meta-analyses: The PRISMA statement. PLoS Med 6(7): e1000097. doi:10.1371/journal.pmed1000097

Mortality in the United States. (2018). https://www.cdc.gov/nchs/products/databriefs/db355.htm

Mularski, R. A., Dy, S. M., Shugarman, L. R., Wilkinson, A. M., Lynn, J., Shekelle, P. G., Morton, S. C., Sun, V. C., Hughes, R. G., Hilton, L. K., Maglione, M., Rhodes, S. L., Rolon, C., \& Lorenz, K. A. (2007). A Systematic Review of measures of end-of-life care and its outcomes. Health Services Research, 42(5), 1848-1870.

https://doi.org/10.1111/j.1475-6773.2007.00721.x

Murillo, M. I., \& Holland, J. C. (2004). Clinical practice guidelines for the management of psychosocial distress at the end of life. Palliative \& Supportive Care, 2(1), 65-77. https://search.proquest.com/docview/214842410?accountid $=45853$

Noble, C., Grealish, L., Teodorczuk, A., Shanahan, B., Hiremagular, B., Morris, J., \& Yardley, S. (2018). How can the end of life care excellence be normalized in hospitals? Lessons from a qualitative framework study. BMC Palliative Care, 17(1), 1-

12. https://doi.org/10.1186/s12904-018-0353-x

Price, D. M., Strodtman, L., Montagnini, M., Smith, H. M., Miller, J., Zybert, J., . . Ghosh, B. (2017). Palliative and end-of-life care education needs of nurses across inpatient care settings. The Journal of Continuing Education in Nursing, 48(7), 329-336. http://dx.doi.org/10.3928/00220124-20170616-10 


\section{EVIDENCE-BASED END-OF-LIFE COMFORT CARE GUIDELINES}

Raijmakers, N. J. H., van Zuylen, L., Costantini, M., Caraceni, A., Clark, J. B., De Simone, G., . .. van der Heide, A. (2012). Issues and needs in end-of-life decision making an international modified delphi study. Palliative Medicine, 26(7), 947-53. http://dx.doi.org/10.1177/0269216311423794

Rancho Los Amigos National Rehabilitation Center. (n.d.). Los Angeles County Department of Health Services-Rancho Los Amigos home http://dhs.lacounty.gov/wps/portal/dhs/rancho Rancho Mission and Vision. (2014, July). Rancho Matters, 7(1), 1-2.

Reid, C., Gibbins, J., Bloor, S., Burcombe, M., McCoubrie, R., \& Forbes, K. (2015). Healthcare professionals' perspectives on delivering end-of-life care within acute hospital trusts: A qualitative study. BMJ Supportive \& Palliative Care, 5(5), 490. http://dx.doi.org/10.1136/bmjspcare-2013-000468

Research and markets; MEDSURG nursing - the official journal of the academy of medicalsurgical nurses AMSN. (2011, Jun 04). Obesity, fitness \& wellness week. https://search.proquest.com/docview/868649502?accountid=158603.

Schriner, C., Deckelman, S., Kubat, M. A., Lenkay, J., Nims, L., \& Sullivan, D. (2010). Collaboration of nursing faculty and college administration in creating organizational change. Nursing Education Perspectives, 31(6), 381-

\section{6. https://search.proquest.com/docview/853717756?accountid=35812}

Shahmoradi, L., Darrudi, A., Arji, G., \& Ahmadreza, F. N. (2017). Electronic health record implementation: A SWOT analysis. Acta Medica Iranica, 55(10), 642649. https://search.proquest.com/docview/1982952727?accountid=158603 


\section{EVIDENCE-BASED END-OF-LIFE COMFORT CARE GUIDELINES}

Shavelson, R. J. (2018). Methodological perspectives: Standardized (summative) or contextualized (formative) evaluation? Education Policy Analysis Archives, 26(45/55), 114. https://doi.org/10.14507/epaa.26.3813

Stacy, A., Magdic, K., Rosenzweig, M., Freeman, B., \& Verosky, D. (2019). Improving knowledge, comfort, and confidence of nurses providing end-of-life care in the hospital setting through use of the CARES tools. Journal of Hospice \& Palliative Nursing, 21(3), 200-2006. https://doi.org/10.1097/NJH.0000000000000510

Stillwell, S. B., \& Scott, J. G. (2020). Sensitive versus specific search strategy to answer clinical questions. Journal of Nursing Education, 59(1), 22-25. https://doi.org/10.3928/01484834-20191223-05

Strech, D., \& Schildmann, J. (2011). Quality of ethical guidelines and ethical content in clinical guidelines: The example of end-of-life decision-making. Journal of Medical Ethics, 37(7), 390. http://dx.doi.org/10.1136/jme.2010.040121

The patient dignity inventory (PDI)- Dignity in care. (n.d.) https://www.dignityincare.ca/wpcontent/uploads/2010/05/The_Patient_Dignity_Inventory.pdf

Virdun, C., Luckett, T., Davidson, P. M., \& Phillips, J. (2015). Dying in the hospital setting: A systematic review of quantitative studies identifying the elements of end-of-life care that patients and their families rank as being most important. Palliative Medicine, 29(9), 774796. http://dx.doi.org/10.1177/0269216315583032

Walker, K., Middleton, S., Rolley, J., \& Duff, J. (2010). Nurses report a healthy culture: Results of the practice environment scale (australia) in an australian hospital seeking magnet recognition. International Journal of Nursing Practice, 16(6), 616-623. http://dx.doi.org/10.1111/j.1440-172X.2010.01890.x 


\section{EVIDENCE-BASED END-OF-LIFE COMFORT CARE GUIDELINES}

White, S., \& Spruce, L. (2015). Perioperative nursing leaders implement clinical practice guidelines using the iowa model of evidence-based practice: The official voice of perioperative nursing. AORN Journal, 102(1), 50-59.

http://dx.doi.org/10.1016/j.aorn.2015.04.001

Xiao, B. L., Frances Kam, Y. W., \& Shirley Siu, Y. C. (2018). The experience of caring for patients at the end-of-life stage in non-palliative care settings: A qualitative study. $B M C$ Palliative Care, 17 http://dx.doi.org/10.1186/s12904-018-0372-7 


\section{EVIDENCE-BASED END-OF-LIFE COMFORT CARE GUIDELINES}

Appendix A

PRISMA Flow Diagram
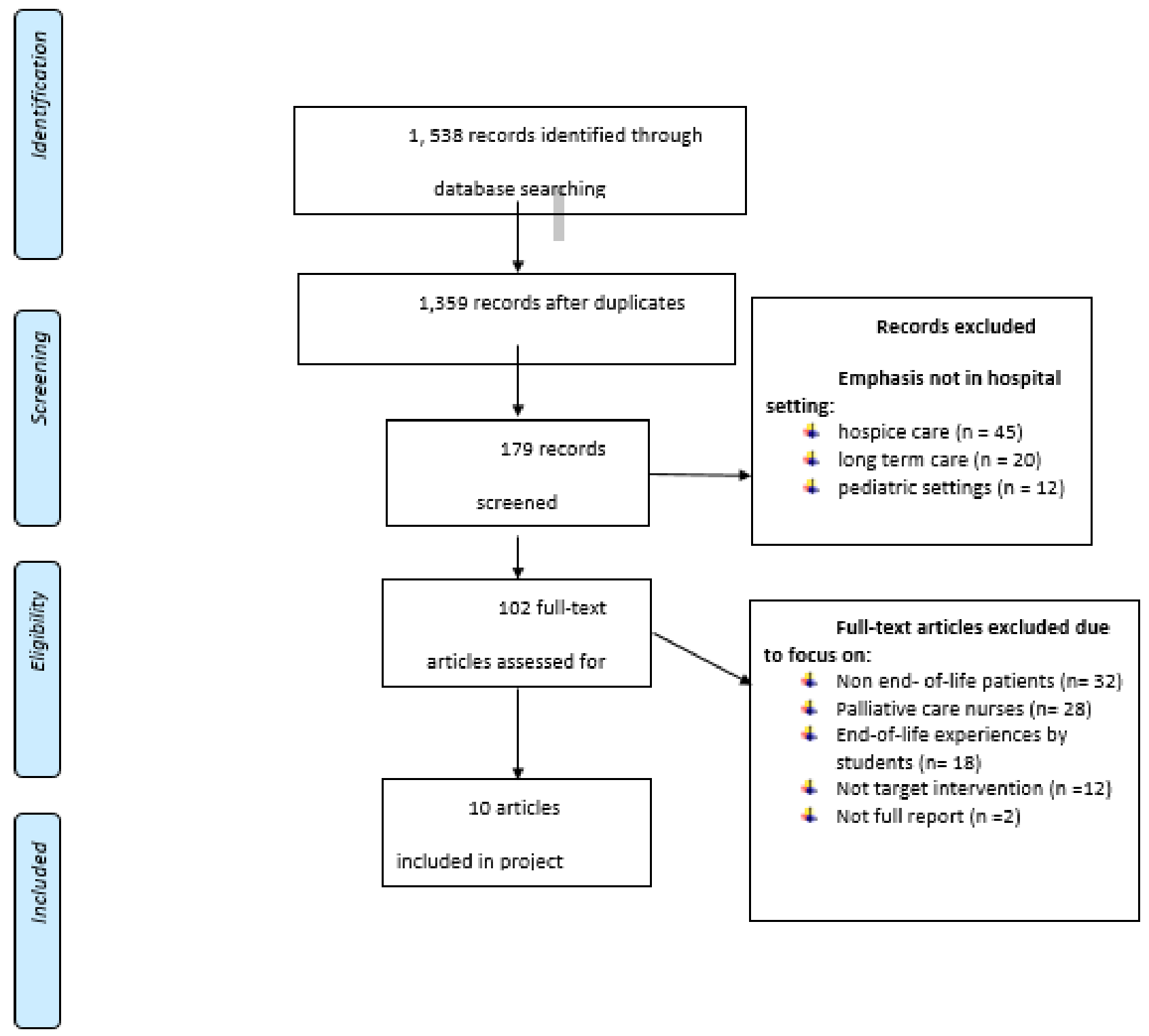

(Moher, Liberati, Tetzlaff, \& Altman, 2009) 


\section{EVIDENCE-BASED END-OF-LIFE COMFORT CARE GUIDELINES}

\section{Appendix B}

\section{Summary of Primary Research Evidence}

\begin{tabular}{|c|c|c|c|c|c|c|}
\hline Citation & $\begin{array}{l}\text { Design } \\
\& \\
\text { Level of } \\
\text { Evidence }\end{array}$ & $\begin{array}{l}\text { Sample } \\
\text { Sample } \\
\text { size }\end{array}$ & $\begin{array}{l}\text { Intervention } \\
\text { Comparison }\end{array}$ & $\begin{array}{l}\text { Theoretical } \\
\text { Foundation }\end{array}$ & Outcome Measure & $\begin{array}{l}\text { Usefulness } \\
\text { Results } \\
\text { Key Findings }\end{array}$ \\
\hline $\begin{array}{l}\text { Beernaert, K., Smets, T., Cohen, J., Verhofstede, } \\
\text { R., Costantini, M., Eecloo, K., . . Deliens, L. } \\
\text { (2017). Improving comfort around dying in } \\
\text { elderly people: A cluster randomized controlled } \\
\text { trial. The Lancet, } 390(10090), 125-134 . \\
\text { http://dx.doi.org/10.1016/S0140-6736(17)31265- } \\
\underline{5}\end{array}$ & $\begin{array}{l}\text { Randomized } \\
\text { Controlled } \\
\text { Trial (RCT) } \\
\text { Level II }\end{array}$ & $\begin{array}{l}451(11 \%) \\
\text { of } 4241 \\
\text { beds in ten } \\
\text { hospitals }\end{array}$ & $\begin{array}{l}\text { A quantitative assessment } \\
\text { instrument was generated to } \\
\text { appraise and monitor the } \\
\text { quality of implementation to } \\
\text { which CAREFuL was } \\
\text { implemented per its protocol. } \\
\text { Several fidelity tests were done } \\
\text { during the intervention } \\
\text { implementation process, such } \\
\text { as whether a project steering } \\
\text { group was formed for the ward. } \\
\text { Used CONSORT guidelines to } \\
\text { design and report the } \\
\text { literature finding. } \\
\text { Used descriptive statistics to } \\
\text { describe the characteristics of } \\
\text { the population and } \chi^{2} \text { tests and } \\
\text { t-tests to illustrate variations } \\
\text { within the control and } \\
\text { CAREFuL groups in baseline } \\
\text { and post-intervention } \\
\text { assessments and post- non- } \\
\text { response analyses. } \\
\text { Scrutinized variations between } \\
\text { the control group and the } \\
\text { CAREFuL group for the } \\
\text { primary and secondary } \\
\text { outcomes with a mixed linear }\end{array}$ & $\begin{array}{l}\text { None } \\
\text { Specified }\end{array}$ & $\begin{array}{l}\text { The outcome measure of } \\
\text { this study was to explore } \\
\text { the effectiveness of care } \\
\text { for a patient in the EOL } \\
\text { sphere using an } \\
\text { evidence-based program } \\
\text { such as CAREFuL, } \\
\text { which mainly focused } \\
\text { on EOL care. }\end{array}$ & $\begin{array}{l}\text { The usefulness results of this study are highly } \\
\text { recognized since the study validated the } \\
\text { significance of the EOL program like } \\
\text { CAREFuL. This evidence-based program } \\
\text { significantly influenced increasing staff } \\
\text { knowledge and recognition of the weight of } \\
\text { lifting the EOL care through the employment of } \\
\text { this pivotal program. Also, it helped the staff } \\
\text { shift their core care focused on the EOL and } \\
\text { educated the team in the offering of } \\
\text { immeasurable EOL care with the support of the } \\
\text { interdisciplinary care guide for the last day } \\
\text { of life. This guide exposes comprehensive } \\
\text { guidelines of evidence-based measures; } \\
\text { including, advocating for the staff's additional } \\
\text { training towards the achievement of sound } \\
\text { knowledge tied to the excellent delivery of } \\
\text { EOL care. } \\
\text { The key analytical finding of the study is that } \\
\text { during the EOL, the uniformity of care as an } \\
\text { outcome of streamlining practice by applying } \\
\text { the care guide is essential to produce positive } \\
\text { impacts on comfort and quality of care, } \\
\text { symptom management, and satisfaction } \\
\text { patient's care needs. }\end{array}$ \\
\hline
\end{tabular}




\section{EVIDENCE-BASED END-OF-LIFE COMFORT CARE GUIDELINES}

\begin{tabular}{|c|c|c|c|c|c|c|}
\hline & & & $\begin{array}{l}\text { regression model that } \\
\text { accounted for the baseline } \\
\text { assessment and the clustered } \\
\text { project study design. }\end{array}$ & & & \\
\hline $\begin{array}{l}\text { Im, J., Mak, S., Upshur, R., Steinberg, L., \& } \\
\text { Kuluski, K. (2019). "Whatever happens, } \\
\text { happens" challenges of end-of-life } \\
\text { communication from the perspective of older } \\
\text { adults and family caregivers: A qualitative } \\
\text { study. BMC Palliative Care, 18(1), 1-9. } \\
\text { https://doi.org/10.1186/s12904-019-0493-7 }\end{array}$ & $\begin{array}{l}\text { Qualitative } \\
\text { research } \\
\text { (interpretive } \\
\text { description } \\
\text { methodology) } \\
\text { Level VI }\end{array}$ & $\begin{array}{l}\text { Purposeful } \\
\text { sampling } \\
\text { and } \\
\text { recruited } 20 \\
\text { patient } \\
\text { participants }\end{array}$ & $\begin{array}{l}\text { The data analysis started with } \\
\text { evaluating the transcripts from } \\
\text { the semi-structured interview, } \\
\text { using open-ended questions. } \\
\text { The data were coded applying } \\
\text { a qualitative data management } \\
\text { software program, NVivo11 } \\
\text { (QSR International). } \\
\text { The thematic interpretation was } \\
\text { employed to code the data to } \\
\text { classify patterns of associated } \\
\text { concepts to yield codes and } \\
\text { themes. Descriptions and } \\
\text { analyses of various excerpts } \\
\text { were matched all over the } \\
\text { transcripts to elucidate the } \\
\text { study question. The applicable } \\
\text { data that correlated to barriers } \\
\text { of EOL care were excerpted } \\
\text { and coded. } \\
\text { The fashion of unfolding } \\
\text { themes and deciphering the } \\
\text { findings entailed examining the } \\
\text { transcripts for various times to } \\
\text { ensure rigor. Impartial with the } \\
\text { research team and the } \\
\text { knowledge exploiters endorsed } \\
\text { to build the integrity and } \\
\text { reliability of the findings. }\end{array}$ & $\begin{array}{l}\text { None } \\
\text { Specified }\end{array}$ & $\begin{array}{l}\text { The outcome definition } \\
\text { or measures of the study } \\
\text { was to identify the } \\
\text { barriers of EOL } \\
\text { communication in } \\
\text { healthcare. }\end{array}$ & $\begin{array}{l}\text { The value of the study's result is apparent as it } \\
\text { offers evidence-based clinical insights that can } \\
\text { appraise ways to integrate EOL discussion with } \\
\text { dying patients. The discoveries stressed a } \\
\text { demand for EOL conversation to start earlier } \\
\text { during the critical progression of the disease. } \\
\text { This premise restored subsidies of patients and } \\
\text { caregivers during a period of deterioration and } \\
\text { for crafting a meaningful connection between } \\
\text { the patient and family members with the } \\
\text { clinician through open communication and } \\
\text { collaboration of care. } \\
\text { The key finding of the study is exhibited } \\
\text { through the naming of four themes in the } \\
\text { meaning of participants' perception of sickness } \\
\text { such as the following: 1) trivializing illness- } \\
\text { related intricacies, 2) positivity in late-life, 3) } \\
\text { apprehension in partaking to EOL dialogues, } \\
\text { and } 4 \text { ) reluctant to take part despite the } \\
\text { compelling necessity. These provocations } \\
\text { usually weave with one another. Most } \\
\text { participants had not shown an interest in EOL } \\
\text { dialogues with their clinicians or family } \\
\text { members. }\end{array}$ \\
\hline $\begin{array}{l}\text { Kisorio, L. C., \& Langley, G. C. (2016). } \\
\text { Intensive care nurses' experiences of end-of-life }\end{array}$ & $\begin{array}{l}\text { Exploratory, } \\
\text { descriptive }\end{array}$ & $\begin{array}{l}\text { Purposive } \\
\text { sampling } \\
\text { method was }\end{array}$ & $\begin{array}{l}\text { The data collection was done } \\
\text { by conducting three focus } \\
\text { groups. Focus group }\end{array}$ & $\begin{array}{l}\text { None } \\
\text { Specified }\end{array}$ & $\begin{array}{l}\text { The outcome definition } \\
\text { of this study was to } \\
\text { unfold the exploration }\end{array}$ & $\begin{array}{l}\text { The key finding of the study is about the } \\
\text { concept that EOL care can be a perverse and } \\
\text { challenging process. }\end{array}$ \\
\hline
\end{tabular}




\section{EVIDENCE-BASED END-OF-LIFE COMFORT CARE GUIDELINES}

\begin{tabular}{|c|c|c|c|c|c|c|}
\hline $\begin{array}{l}\text { care. Intensive \& Critical Care Nursing, 33, 30- } \\
\text { 38. http://dx.doi.org/10.1016/j.iccn.2015.11.002 }\end{array}$ & $\begin{array}{l}\text { qualitative } \\
\text { approach } \\
\text { Level VI }\end{array}$ & $\begin{array}{l}\text { used to } \\
\text { select nurse } \\
\text { participants } \\
(\mathrm{n}=24) \\
\text { working at } \\
\text { the selected } \\
\text { intensive } \\
\text { care units }\end{array}$ & $\begin{array}{l}\text { discussions were performed } \\
\text { four weeks apart during the day } \\
\text { in a private room near the unit. } \\
\text { Verbatim transcription was } \\
\text { done promptly following each } \\
\text { focus group conversation in } \\
\text { preparation for data analysis. } \\
\text { Field notes were inserted in the } \\
\text { transcripts. Each transcript was } \\
\text { read and re-read in conjunction } \\
\text { with the audio-taped recording } \\
\text { and corrections made where } \\
\text { necessary. Data were then } \\
\text { analyzed, applying the long- } \\
\text { table approach, which enabled } \\
\text { the researchers to categorize } \\
\text { results and distinguish the } \\
\text { theme. } \\
\text { A descriptive summary of each } \\
\text { group's responses was written } \\
\text { to bear comparison and } \\
\text { contrast, featuring distinct, } \\
\text { detailed, and often discussed } \\
\text { comments. Following the } \\
\text { descriptive review for each of } \\
\text { the questions, themes, and sub- } \\
\text { themes were developed by } \\
\text { looking for things that came up } \\
\text { repeatedly across the questions. } \\
\text { The integrity of the study was } \\
\text { maintained following criteria } \\
\text { by Lincoln and Guba (1985). } \\
\text { Conformability was attained by } \\
\text { having transcripts analyzed } \\
\text { individually by both authors } \\
\text { before meeting together to } \\
\text { compare, correlate, and discuss } \\
\text { the emerging theme. }\end{array}$ & & $\begin{array}{l}\text { strain experiences of } \\
\text { intensive care nurses } \\
\text { associated with nurses' } \\
\text { engagements with EOL } \\
\text { care. }\end{array}$ & $\begin{array}{l}\text { The result's usefulness in nursing practice is } \\
\text { central to the indication it offers. It features } \\
\text { some of the interventions and support systems } \\
\text { that could be adopted to enhance EOL's caring } \\
\text { process. Additionally, the evidence illustrates } \\
\text { that dying patients and their families command } \\
\text { to be supported, and the nurses should also be } \\
\text { cared for to provide the best possible EOL } \\
\text { care. }\end{array}$ \\
\hline $\begin{array}{l}\text { Noble, C., Grealish, L., Teodorczuk, A., } \\
\text { Shanahan, B., Hiremagular, B., Morris, J., \& } \\
\text { Yardley, S. (2018). How can the end of life care } \\
\text { excellence be normalized in hospitals? Lessons }\end{array}$ & $\begin{array}{l}\text { Explanatory } \\
\text { qualitative } \\
\text { interview } \\
\text { design }\end{array}$ & $\begin{array}{l}\text { Purposive } \\
\text { sample of } \\
28 \text { acute } \\
\text { wards and }\end{array}$ & $\begin{array}{l}\text { Data generated via semi- } \\
\text { structured interviews of the } \\
\text { participants. Analyzed data } \\
\text { were employing a five-phase }\end{array}$ & $\begin{array}{l}\text { Normalization } \\
\text { Process } \\
\text { Theory (NPT) }\end{array}$ & $\begin{array}{l}\text { The outcome measure of } \\
\text { the study was to explore } \\
\text { if and how EOL care } \\
\text { merit of excellence can }\end{array}$ & $\begin{array}{l}\text { The key finding of the study offers strategies } \\
\text { for normalizing EOL care worth in the acute } \\
\text { care setting using guidelines. Further } \\
\text { exploration into these experiences will provide }\end{array}$ \\
\hline
\end{tabular}




\section{EVIDENCE-BASED END-OF-LIFE COMFORT CARE GUIDELINES}

\begin{tabular}{|c|c|c|c|c|c|c|}
\hline $\begin{array}{l}\text { from a qualitative framework study. } B M C \\
\text { Palliative Care, } 17(1), 1- \\
\text { 12. https://doi.org/10.1186/s12904-018-0353-x }\end{array}$ & Level VI & $\begin{array}{l}18 \text { staff } \\
\text { participated }\end{array}$ & 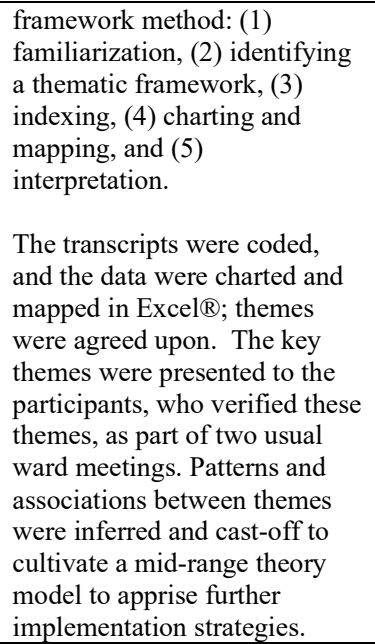 & & $\begin{array}{l}\text { be entrenched or } \\
\text { normalized after } \\
\text { implementing the } \\
\text { Clinical Guidelines for } \\
\text { Dying Patients }(\mathrm{CgDp}) \\
\text { in the acute care setting. }\end{array}$ & $\begin{array}{l}\text { insights into how these tensions might be } \\
\text { reconciled and held to warrant holistic EOL in } \\
\text { acute care settings. } \\
\text { The results' usefulness is based on empirical } \\
\text { evidence from healthcare practitioners working } \\
\text { in acute care settings on their experiences of } \\
\text { providing EOL care. The CgDp model fosters } \\
\text { the supremacy of interprofessional and } \\
\text { interdisciplinary working cohesively utilizing } \\
\text { evidence-based strategies to strengthen their } \\
\text { aptitudes for fastening the value of EOL quality } \\
\text { care while led by experienced palliative care } \\
\text { teams. }\end{array}$ \\
\hline $\begin{array}{l}\text { Price, D. M., Strodtman, L., Montagnini, M., } \\
\text { Smith, H. M., Miller, J., Zybert, J., ... Ghosh, B. } \\
\text { (2017). Palliative and end-of-life care education } \\
\text { needs of nurses across inpatient care settings. The } \\
\text { Journal of Continuing Education in } \\
\text { Nursing, 48(7), 329-336. } \\
\text { http://dx.doi.org/10.3928/00220124-20170616-10 } \\
\end{array}$ & $\begin{array}{l}\text { Descriptive } \\
\text { and } \\
\text { correlational } \\
\text { quantitative } \\
\text { study } \\
\text { Level VI }\end{array}$ & $\begin{array}{l}583 \text { nurses } \\
\text { completed } \\
\text { the surveys } \\
(182 \text { from } \\
\text { acute care } \\
\text { units, } 227 \\
\text { from adult } \\
\text { ICU, } 85 \\
\text { nurses from } \\
\text { the acute } \\
\text { care } \\
\text { pediatrics } \\
\text { and } 89 \\
\text { nurses from } \\
\text { pediatric } \\
\text { ICU) }\end{array}$ & $\begin{array}{l}\text { Collected data were } \\
\text { scrutinized, applying SAS } \\
\text { version } 9.4 \text { software. Means } \\
\text { were calculated for each EOL } \\
\text { domain subscale to identify } \\
\text { areas of highest perceived } \\
\text { competency and deficiency. } \\
\text { The inherent distinctions } \\
\text { among the pediatric and adult } \\
\text { units in acute and intensive } \\
\text { care settings for the EOL care } \\
\text { domain subscales were } \\
\text { computed utilizing a one-way } \\
\text { ANOVA. } \\
\text { Correlations were calculated to } \\
\text { explore the association within } \\
\text { demographic variables and } \\
\text { mean scores of the EOL } \\
\text { domain subscales. } \\
\text { Cronbach's alpha exhibited } \\
\text { satisfactory to high internal } \\
\text { consistency reliability for the } \\
\text { EOLC-Q in all adult and } \\
\text { pediatric settings in the current } \\
\text { study (alpha range = .68 to } .93\end{array}$ & $\begin{array}{l}\text { None } \\
\text { specified }\end{array}$ & $\begin{array}{l}\text { The outcome measures } \\
\text { of the study were to } \\
\text { ascertain how to } \\
\text { improve the patient } \\
\text { experience during the } \\
\text { EOL expedition in the } \\
\text { inpatient settings. }\end{array}$ & $\begin{array}{l}\text { The key finding of the study revealed that } \\
\text { nursing educational demands concerning the } \\
\text { domains of palliative and EOL care might be } \\
\text { dissimilar according to patient population and } \\
\text { the level of care acuity and associated with } \\
\text { staff's demographic variables and an inordinate } \\
\text { length of time in current practice. } \\
\text { The result of the study's usefulness relies on its } \\
\text { recommendation to concentrate deeper on } \\
\text { serving the patient with transitions in care, } \\
\text { aiding patient and family wishes, and fostering } \\
\text { continuum of care between inpatient and } \\
\text { outpatient settings in the acute care and } \\
\text { pediatric environment. Also, the study } \\
\text { understood the necessity for all of the nursing } \\
\text { units to have resources accessible to raise } \\
\text { essential competencies in rendering quality } \\
\text { palliative and EOL care and prospects to gain } \\
\text { provisional staff support as compelled. }\end{array}$ \\
\hline
\end{tabular}




\section{EVIDENCE-BASED END-OF-LIFE COMFORT CARE GUIDELINES}

\begin{tabular}{|c|c|c|c|c|c|c|}
\hline & & & $\begin{array}{l}\text { for the total sample), except the } \\
\text { emotional support for staff } \\
\text { subscale (alpha }=.17) \text {. } \\
\text { Open-ended responses were } \\
\text { investigated and assorted to } \\
\text { add significance to the } \\
\text { quantitative data } \\
\text { The investigation was } \\
\text { considered to be finished when } \\
\text { there was duplication, and } \\
\text { saturation of theme was } \\
\text { identified }\end{array}$ & & & \\
\hline $\begin{array}{l}\text { Reid, C., Gibbins, J., Bloor, S., Burcombe, M., } \\
\text { McCoubrie, R., \& Forbes, K. (2015). Healthcare } \\
\text { professionals' perspectives on delivering end-of- } \\
\text { life care within acute hospital trusts: A qualitative } \\
\text { study. BMJ Supportive \& Palliative Care, 5(5), } \\
\text { 490. http://dx.doi.org/10.1136/bmjspcare-2013- } \\
\underline{000468}\end{array}$ & $\begin{array}{l}\text { Qualitative } \\
\text { research } \\
\text { method (focus } \\
\text { group, in- } \\
\text { depth } \\
\text { interviews } \\
\text { Level VI }\end{array}$ & $\begin{array}{l}\text { Six focus } \\
\text { groups } \\
\text { (FGs) with } \\
\text { a range of } \\
\text { staff in } \\
\text { medical- } \\
\text { surgical, } \\
\text { orthopedic, } \\
\text { and elderly } \\
\text { wards }\end{array}$ & $\begin{array}{l}\text { Focus groups, semi-structured } \\
\text { interviews were how the data } \\
\text { were collected. These focus } \\
\text { group interviews were } \\
\text { conducted both before and after } \\
\text { the EOL tool implementation } \\
\text { and lasted from } 60 \text { to } 120 \text { min. } \\
\text { Transcripts and FGs were taped } \\
\text { and deciphered verbatim. } \\
\text { Participants were queried about } \\
\text { their experiences of furnishing } \\
\text { EOL care in hospital, how } \\
\text { various assortments of staff } \\
\text { communicated during EOL } \\
\text { care, and their experience } \\
\text { utilizing the EOL instrument } \\
\text { once it had been implemented. } \\
\text { The quester views were } \\
\text { conducted on the wards as staff } \\
\text { filled up the EOL tool } \\
\text { checklists. The transcripts were } \\
\text { scrutinized, and emerging } \\
\text { themes were established. }\end{array}$ & $\begin{array}{l}\text { None } \\
\text { Specified }\end{array}$ & $\begin{array}{l}\text { The outcome measure of } \\
\text { the study was to explore } \\
\text { the healthcare } \\
\text { professionals' views on } \\
\text { delivering EOL care } \\
\text { within acute care } \\
\text { settings since the } \\
\text { evidence showed that } \\
\text { the quality of EOL care } \\
\text { in acute hospitals varies } \\
\text { and the available } \\
\text { pathways as } \\
\text { interventions were not } \\
\text { being used to improve } \\
\text { EOL care. }\end{array}$ & $\begin{array}{l}\text { This study revealed that the EOL tool has a } \\
\text { tangible impact on nursing practice since it } \\
\text { yielded a structured method for EOL care. It } \\
\text { enabled the nurses to challenge some of the } \\
\text { medical interventions that were being rendered } \\
\text { to patients, which might not necessarily be } \\
\text { needed for patients on the active phase of } \\
\text { dying. } \\
\text { The result of the study's usefulness is its } \\
\text { offering that proper EOL care can only be } \\
\text { performed if any healthcare institution's culture } \\
\text { acknowledges death and dying as a conceivable } \\
\text { outcome for patients. Therefore, the emphasis } \\
\text { is on the culture reformation and improved } \\
\text { communication } \\
\text { There are two dominant themes derived from } \\
\text { the study. First, it had the impediments or } \\
\text { delays in diagnosing dying due to complexity, } \\
\text { restraint, and cultural and structural issues. } \\
\text { Second, the positive effect of having the EOL } \\
\text { tool rendering provisional support for staff. }\end{array}$ \\
\hline $\begin{array}{l}\text { Stacy, A., Magdic, K., Rosenzweig, M., Freeman, } \\
\text { B., \& Verosky, D. (2019). Improving knowledge, } \\
\text { comfort, and confidence of nurses providing end- } \\
\text { of-life care in the hospital setting through use of } \\
\text { the CARES tools. Journal of Hospice \& } \\
\text { Palliative Nursing, 21(3), 200-2006. }\end{array}$ & $\begin{array}{l}\text { Quasi- } \\
\text { experimental } \\
\text { design }\end{array}$ & $\begin{array}{l}\text { Convenience } \\
\text { sampling of } \\
\text { registered } \\
\text { nurses }(9 \\
\text { nurses) on a } \\
16 \text { - bed } \\
\end{array}$ & $\begin{array}{l}\text { A paired sample t-test was } \\
\text { directed employing SPSS for } \\
\text { comparison of survey results } \\
\text { with a calculated significance } \\
\text { level of less than } 0.05 \text {. }\end{array}$ & $\begin{array}{l}\text { Plan-do- } \\
\text { study-act } \\
\text { (PDSA) }\end{array}$ & $\begin{array}{l}\text { The outcome definition } \\
\text { or measure of this study } \\
\text { was to examine if the } \\
\text { comfort and the } \\
\text { knowledge of the } \\
\text { nursing participants of }\end{array}$ & $\begin{array}{l}\text { The key finding from this study is the validity } \\
\text { of the assumption that improving the } \\
\text { EOL experience for families of the dying is a } \\
\text { central locus for quality improvement that can } \\
\text { be actualized by utilizing the CARES tool. It is } \\
\text { heavily supported by the outcome of the study }\end{array}$ \\
\hline
\end{tabular}




\section{EVIDENCE-BASED END-OF-LIFE COMFORT CARE GUIDELINES}

\begin{tabular}{|c|c|c|c|c|c|c|}
\hline https://doi.org/10.1097/NJH.0000000000000510 & LEVEL III & $\begin{array}{l}\text { medical } \\
\text { progressive } \\
\text { care unit }\end{array}$ & $\begin{array}{l}\text { All post-intervention survey } \\
\text { scores improved following } \\
\text { the adoption of CARES tool. } \\
\text { Of these segments, five of } \\
\text { nine post-intervention survey } \\
\text { changes were statistically } \\
\text { significant. These five } \\
\text { elements involved (1) } \\
\text { knowledge about EOL care, } \\
\text { understanding, and comfort in } \\
\text { discussing symptoms } \\
\text { including (2) comfort/pain } \\
\text { management, (3) airway, (4) } \\
\text { emotional support of the } \\
\text { patient and his/her family, } \\
\text { and (5) confidence in } \\
\text { conversing on the dying } \\
\text { process with families of the } \\
\text { suffering patient. }\end{array}$ & & $\begin{array}{l}\text { the study improved } \\
\text { through the utilization } \\
\text { of CARES tools. } \\
\text { CARES tool is an } \\
\text { acronym constructed } \\
\text { based on the everyday } \\
\text { symptom management } \\
\text { needs of the dying: } \\
\text { comfort, airway, } \\
\text { restlessness and } \\
\text { delirium, emotional and } \\
\text { spiritual support, and } \\
\text { self-care. }\end{array}$ & $\begin{array}{l}\text { showing that CARES tool for nurses enhanced } \\
\text { nursing expertise and satisfaction linked to } \\
\text { EOL care and everyday symptom management } \\
\text { needs of the dying. }\end{array}$ \\
\hline $\begin{array}{l}\text { Xiao, B. L., Frances Kam, Y. W., \& Shirley Siu, } \\
\text { Y. C. (2018). The experience of caring for } \\
\text { patients at the end-of-life stage in non-palliative } \\
\text { care settings: A qualitative study. BMC Palliative } \\
\text { Care, } 17 \text { http://dx.doi.org/10.1186/s12904-018- } \\
\text { 0372-7 }\end{array}$ & $\begin{array}{l}\text { Qualitative } \\
\text { Study } \\
\text { Level VI }\end{array}$ & $\begin{array}{l}26 \text { healthcare } \\
\text { providers } \\
\text { from eight } \\
\text { health care } \\
\text { institutions } \\
\text { such as acute } \\
\text { care, sub- } \\
\text { acute or } \\
\text { primary care }\end{array}$ & $\begin{array}{l}\text { Data were solicited through } \\
\text { interviews and analyzed using } \\
\text { qualitative content analysis. } \\
\text { All of the meetings were } \\
\text { audiotaped and averaged } 41 \\
\text { minutes in time. Participant } \\
\text { recruitment was concluded } \\
\text { when data saturation was } \\
\text { achieved. } \\
\text { Data saturation was } \\
\text { ascertained utilizing the } \\
\text { criterion of informational } \\
\text { redundancy suggested by } \\
\text { Grady and Sandelowski. } \\
\text { When the researcher } \\
\text { commenced hearing similar } \\
\text { remarks repeatedly in } \\
\text { multiple instances during the } \\
\text { interviews, the acquisition of } \\
\text { data saturation was deemed } \\
\text { achieved. } \\
\text { The precision or rigor of a } \\
\text { study relates to its credibility, } \\
\text { transferability, dependability, }\end{array}$ & $\begin{array}{l}\text { None } \\
\text { specified }\end{array}$ & $\begin{array}{l}\text { The outcome measure of } \\
\text { the study was to explore } \\
\text { the experiences of } \\
\text { health care providers in } \\
\text { caring for patients at the } \\
\text { EOL stage in non- } \\
\text { palliative care settings } \\
\text { to } \\
\text { discover the factual } \\
\text { challenges and } \\
\text { difficulties they faced } \\
\text { with rendering EOL } \\
\text { care in the non- } \\
\text { palliative care setting. }\end{array}$ & $\begin{array}{l}\text { The key finding of the study spoke to the } \\
\text { prospect of the EOL care system of tomorrow, } \\
\text { which should cover health care organizations at } \\
\text { all levels, with entrenched mechanisms of } \\
\text { collaboration among establishments. } \\
\text { The result's usefulness promoted the landscape } \\
\text { of EOL care, which should be delivered to } \\
\text { patients with various life-threatening diseases } \\
\text { in both palliative and non-palliative care } \\
\text { contexts. Highlighting the evidence of } \\
\text { upholding the need to express the impediments } \\
\text { to the development of EOL care; therefore, it } \\
\text { required the commitment of health care } \\
\text { providers, patients and their families, and the } \\
\text { health care system as a whole. }\end{array}$ \\
\hline
\end{tabular}




\section{EVIDENCE-BASED END-OF-LIFE COMFORT CARE GUIDELINES}

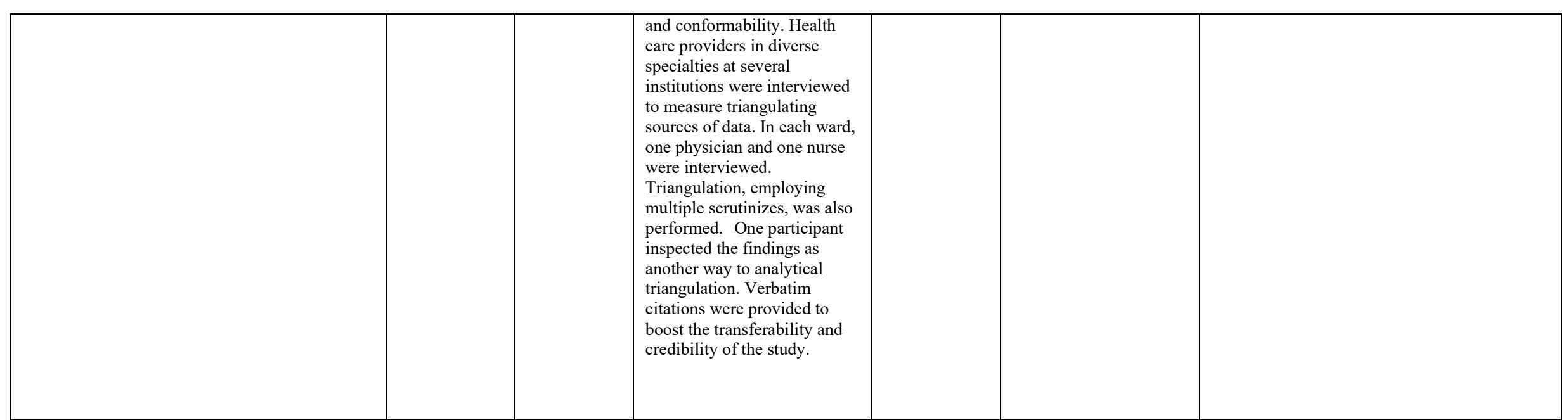

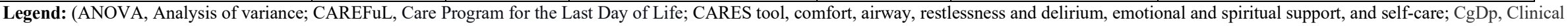

Guidelines for Dying Patient; EOL, End-of-Life; FG (s), Focus groups; NPT, Normalization Process Theory; PDSA, Plan, Do, Study, Act). 
EVIDENCE-BASED END-OF-LIFE COMFORT CARE GUIDELINES

Appendix C

\section{Summary of Systematic Reviews (SR)}

\begin{tabular}{|c|c|c|c|c|c|c|c|}
\hline Citation & \begin{tabular}{|c|} 
Quality \\
Grade
\end{tabular} & Question & Search Strategy & $\begin{array}{l}\text { Inclusion/ } \\
\text { Exclusion Criteria }\end{array}$ & $\begin{array}{l}\text { Data Extraction and } \\
\text { Analysis }\end{array}$ & Key Findings & $\begin{array}{l}\text { Usefulness/Recom } \\
\text { mendation/ } \\
\text { Implications }\end{array}$ \\
\hline \begin{tabular}{|l|} 
Carvajal, A., \\
Haraldsdottir, E., Kroll, \\
T., McCormack, B., \\
Errasti-Ibarrondo, B., \& \\
Larkin, P. (2019). \\
Barriers and facilitators \\
perceived by registered \\
nurses in providing \\
person-centered care at \\
the end of life. A scoping \\
review. International \\
Practice Development \\
Oournal, $9(2), 1-22$. \\
https://doi.org/10.19043/i \\
pdj.92.008
\end{tabular} & Level V & $\begin{array}{l}\text { What are the barriers } \\
\text { and facilitators to } \\
\text { providing person- } \\
\text { centered end-of-life } \\
\text { care for generalist } \\
\text { registered nurses? }\end{array}$ & $\begin{array}{l}\text { Six databases such as } \\
\text { CINAHL, Medline, PsycINFO, } \\
\text { Web of Science, Embase, and } \\
\text { Cochrane reviews were } \\
\text { searched using the date of } 2000 \\
\text { to } 2018 \text {, which covered the } \\
\text { primary studies related to } \\
\text { person-centered care. A search } \\
\text { of the grey literature that } \\
\text { included repositories, catalogs, } \\
\text { and websites was also carried } \\
\text { out. Additional references were } \\
\text { located through an examination } \\
\text { of the references from the } \\
\text { selected studies identified from } \\
\text { the databases search. Articles } \\
\text { in English were selected. Both } \\
\text { MeSH terms and free text } \\
\text { search were used on the } \\
\text { individual databases with the } \\
\text { following search terms: } \\
\text { (Nurs*) AND ('Person- } \\
\text { centered care' OR 'patient } \\
\text { centred care' \{Mesh Term\} OR } \\
\text { 'person centr*' OR 'Patient- } \\
\text { focused care' OR Patient's } \\
\text { beliefs and values OR } \\
\text { Engagement OR 'shared } \\
\text { decision making' OR } \\
\text { Sympathetic presence OR } \\
\text { 'Holistic care' OR } \\
\text { 'Professional competence' OR } \\
\text { Interpersonal skills OR } \\
\text { Commitment OR 'Knowing } \\
\text { self') AND ('Palliative care' } \\
\text { OR 'end of life' OR 'advance } \\
\end{array}$ & $\begin{array}{l}\text { The inclusion criteria were } \\
\text { as follows: } \\
\text { Empirical studies, non- } \\
\text { empirical studies (not limited } \\
\text { to any specific research } \\
\text { design). } \\
\text { Reviews that were converging } \\
\text { on experiences of generalist } \\
\text { nurses providing end-of-life } \\
\text { care in adult populations and } \\
\text { any setting. } \\
\text { The exclusion criteria were } \\
\text { as follows: } \\
\text { Empirical and non-empirical } \\
\text { studies that directed on } \\
\text { experiences of } \\
\text { specialist/hospice nurses in } \\
\text { providing end-of-life care. } \\
\text { Researches that were } \\
\text { concentrating on the } \\
\text { experiences of } \\
\text { patients/families of end-of-life } \\
\text { care. } \\
\text { Research centered on nurses' } \\
\text { experiences at the early stages } \\
\text { of the illness. }\end{array}$ & $\begin{array}{l}\text { A total of 2,126 } \\
\text { publications were } \\
\text { identified, with } 26 \\
\text { preserved after employing } \\
\text { the eligibility criteria. } \\
\text { The data were extricated } \\
\text { systematically } \\
\text { in summary charts; } \\
\text { including, author, year, } \\
\text { country, aim, study } \\
\text { population, setting, } \\
\text { methodology, and findings. } \\
\text { Synthesis, analysis, and } \\
\text { interpretation of the data } \\
\text { observed the measures } \\
\text { outlined by Arksey and } \\
\text { O'Malley, which } \\
\text { comprised the } \\
\text { identification of the } \\
\text { research question and } \\
\text { relevant studies, study } \\
\text { selection, data charting, } \\
\text { and collating, and } \\
\text { summarizing of results and } \\
\text { reporting of findings. The } \\
\text { Person-centered Practice } \\
\text { Framework of McCormack } \\
\text { and McCance (2017) was } \\
\text { adopted to identify and } \\
\text { define the barriers and } \\
\text { facilitators ascertained in } \\
\text { the literature. Outcomes } \\
\text { were mapped against the } \\
\text { constructs of the } \\
\text { framework. } \\
\end{array}$ & $\begin{array}{l}\text { The key finding from this } \\
\text { study is specific to the } \\
\text { essential elements perceived to } \\
\text { exhibit the construction of the } \\
\text { person-centered practice } \\
\text { framework. It means solely } \\
\text { knowing the person who is the } \\
\text { patient and the family; } \\
\text { including, the self-knowledge } \\
\text { of a nurse on the creation of a } \\
\text { valuable nurse-person alliance. } \\
\\
\text { The significant findings that } \\
\text { can be beneficial to nursing } \\
\text { practice in dealing with EOL } \\
\text { care are identifying the four } \\
\text { essential barriers and } \\
\text { facilitators to implementing } \\
\text { person-centered. These are } \\
\text { explicit with the knowledge of } \\
\text { end-of-life care } \\
\text { communication skills, coping } \\
\text { maneuverings, and teamwork. } \\
\text { The three principal facilitators } \\
\text { recognized are knowing the } \\
\text { person in a holistic way, } \\
\text { nurses' self-knowledge, and the } \\
\text { development of an excellent } \\
\text { nurse-person relationship. } \\
\text { Reliable support from the } \\
\text { organization and leadership } \\
\text { also was found to be necessary. } \\
\text { These conclusions are depicted } \\
\text { in the conceptual elements } \\
\text { from the } 2017 \text { McCormack and }\end{array}$ & $\begin{array}{l}\text { The study's } \\
\text { recommendation is to } \\
\text { weave the concept of } \\
\text { person-centeredness in } \\
\text { EOL care. This idea can } \\
\text { be strengthened by } \\
\text { training the nurses about } \\
\text { EOL care components } \\
\text { applying the person- } \\
\text { centered practice } \\
\text { framework. }\end{array}$ \\
\hline
\end{tabular}


EVIDENCE-BASED END-OF-LIFE COMFORT CARE GUIDELINES

\begin{tabular}{|c|c|c|c|c|c|c|c|}
\hline Citation & $\begin{array}{c}\text { Quality } \\
\text { Grade }\end{array}$ & Q Question & Search Strategy & $\begin{array}{l}\text { Inclusion/ } \\
\text { Exclusion Criteria }\end{array}$ & $\begin{array}{l}\text { Data Extraction and } \\
\text { Analysis }\end{array}$ & Key Findings & $\begin{array}{l}\text { Usefulness/Recom } \\
\text { mendation/ } \\
\text { Implications }\end{array}$ \\
\hline & & & $\begin{array}{l}\text { disease' OR 'advanced } \\
\text { illness'). }\end{array}$ & & $\begin{array}{l}\text { The heterogeneity of the } \\
\text { included articles made it } \\
\text { impossible to carry out a } \\
\text { meta-analysis of data. } \\
\text { Instead, the chosen studies } \\
\text { are summarized. A } \\
\text { straightforward appraisal } \\
\text { of methodological quality } \\
\text { was not conducted as the } \\
\text { aim of the scoping review } \\
\text { was not to examine the } \\
\text { quality of the evidence but } \\
\text { to reach a full overview of } \\
\text { existing evidence. }\end{array}$ & $\begin{array}{l}\text { McCance's Person-centered } \\
\text { Practice Framework. }\end{array}$ & \\
\hline $\begin{array}{l}\text { Virdun, C., Luckett, T., } \\
\text { Davidson, P. M., \& } \\
\text { Phillips, J. (2015). Dying } \\
\text { in the hospital setting: A } \\
\text { systematic review of } \\
\text { quantitative studies } \\
\text { identifying the elements } \\
\text { of end-of-life care that } \\
\text { patients and their families }\end{array}$ & Level V & $\begin{array}{l}\text { What are the five } \\
\text { elements of end-of-life } \\
\text { care that quantitative } \\
\text { studies suggest are } \\
\text { most important to } \\
\text { hospitalized patients } \\
\text { with palliative care } \\
\text { needs and their } \\
\text { families? }\end{array}$ & $\begin{array}{l}\text { Databases included the } \\
\text { following: Academic Search } \\
\text { Complete (EBSCO), AMED } \\
\text { (OVID), CINAHL (EBSCO), } \\
\text { MEDLINE (EBSCO), } \\
\text { MEDLINE (OVID), EMBASE } \\
\text { (OVID), PsycINFO (OVID), } \\
\text { PubMed and Cochrane. } \\
\text { Desktop searching of the }\end{array}$ & $\begin{array}{l}\text { Inclusion Criteria: } \\
\text { Quantitative English peer- } \\
\text { reviewed journals between } \\
\text { 1990-2004. } \\
\text { Studies reported empirical } \\
\text { patient and/or family data's } \\
\text { enunciating "importance" } \\
\text { related to EOL care in } \\
\text { hospitals or scrutinized } \\
\end{array}$ & \begin{tabular}{l}
\multicolumn{1}{c}{ The data } \\
analysis and data \\
extraction were initiated \\
through conspicuous \\
tabularization and content \\
analysis. Content analysis \\
ensued over the \\
organization of data into \\
care domains or \\
\end{tabular} & $\begin{array}{l}\text { The key findings of the study } \\
\text { were central to the identified } \\
\text { domains and are as follows: } \\
\text { effective communication and } \\
\text { shared decision making with a } \\
\text { particular allusion to restricting } \\
\text { futile treatments and instead } \\
\text { empowering preparation for } \\
\text { ELO care; expert EOL care at }\end{array}$ & $\begin{array}{l}\text { The study's usefulness } \\
\text { relates to its conclusion } \\
\text { that it is imperative to } \\
\text { understand that in } \\
\text { developing and } \\
\text { implementing models of } \\
\text { EOL care for the hospital } \\
\text { setting, it should be } \\
\text { based on data outlining }\end{array}$ \\
\hline
\end{tabular}


EVIDENCE-BASED END-OF-LIFE COMFORT CARE GUIDELINES

\begin{tabular}{|c|c|c|c|c|c|c|c|}
\hline Citation & $\begin{array}{l}\text { Quality } \\
\text { Grade }\end{array}$ & Question & Search Strategy & $\begin{array}{l}\text { Inclusion/ } \\
\text { Exclusion Criteria }\end{array}$ & $\begin{array}{l}\text { Data Extraction and } \\
\text { Analysis }\end{array}$ & Key Findings & $\begin{array}{l}\text { Usefulness/Recom } \\
\text { mendation/ } \\
\text { Implications }\end{array}$ \\
\hline \begin{tabular}{|l|} 
rank as being most \\
important. Palliative \\
Medicine, 29(9), 774- \\
796. \\
http://dx.doi.org/10.1177/ \\
0269216315583032 \\
\end{tabular} & & & $\begin{array}{l}\text { internet via Google and Google } \\
\text { Scholar search engines, Care } \\
\text { Search, and hand searching was } \\
\text { also completed. The reference } \\
\text { lists of all included studies and } \\
\text { other relevant reviews were } \\
\text { searched manually to detect } \\
\text { other theoretically germane } \\
\text { research studies. }\end{array}$ & \begin{tabular}{|l} 
statistically satisfaction data \\
that signify qualified \\
significance by finding which \\
components of care had \\
higher satisfaction levels. \\
Exclusion Criteria: \\
Qualitative studies failed to \\
deliver crucial data from \\
patients or family members, \\
were not in English, provided \\
outcome measures that did not \\
include an emphasis on the \\
concept of importance, \\
delivered diminutive or no \\
concentration on EOL care in \\
the hospital setting, \\
pronounced experience and/or \\
satisfaction only (without \\
providing data to inform \\
understanding of the care \\
elements related to this), \\
described on a primary data \\
set already counted in without \\
pertinent, innovative \\
standpoints provided or \\
received a quality rating of 2 \\
or less for 'relevance to \\
question', with this being one \\
of a suite of measures \\
developed for appraising \\
evidence for palliative care \\
guidelines in Australia.
\end{tabular} & $\begin{array}{l}\text { overarching categories. } \\
\text { Elements of care rated as } \\
\text { the uppermost five most } \\
\text { significant in each article } \\
\text { were tabularized, } \\
\text { scrutinized, and clustered } \\
\text { into domains. The initial } \\
\text { domains were assembled } \\
\text { before moving to appraisal } \\
\text { by the team. Where there } \\
\text { was a divergence in view, } \\
\text { the dialogue was seized to } \\
\text { grasp consensus. The } \\
\text { frequency of each domain } \\
\text { was summarized as an } \\
\text { index of overall priority } \\
\text { from a patient and family } \\
\text { perspective. Where data } \\
\text { were pooled through } \\
\text { articles, the frequency } \\
\text { count was only considered } \\
\text { once. }\end{array}$ & \begin{tabular}{|l||} 
any points with a distinct \\
recommendation to \\
immeasurable physical care, \\
symptom management, and \\
integrated care; courteous and \\
compassionate care with \\
precise attention to the \\
preservation of dignity; trust \\
and confidence in clinicians; \\
and a satisfactory environment \\
for health care services \\
worldwide.
\end{tabular} & \begin{tabular}{|l} 
what is most relevant and \\
valuable for patients, \\
such as comfort care \\
needs as well as the \\
individualized \\
compelling families' \\
needs. \\
The study's \\
recommendation is to \\
develop and appraise \\
models of care, \\
generalizing the \\
identified domains of \\
care for all patients with \\
EOL care needs.
\end{tabular} \\
\hline
\end{tabular}

Legend: (EOL, End-of-Life) 
EVIDENCE-BASED END-OF-LIFE COMFORT CARE GUIDELINES

Appendix D

\section{SWOT Analysis}

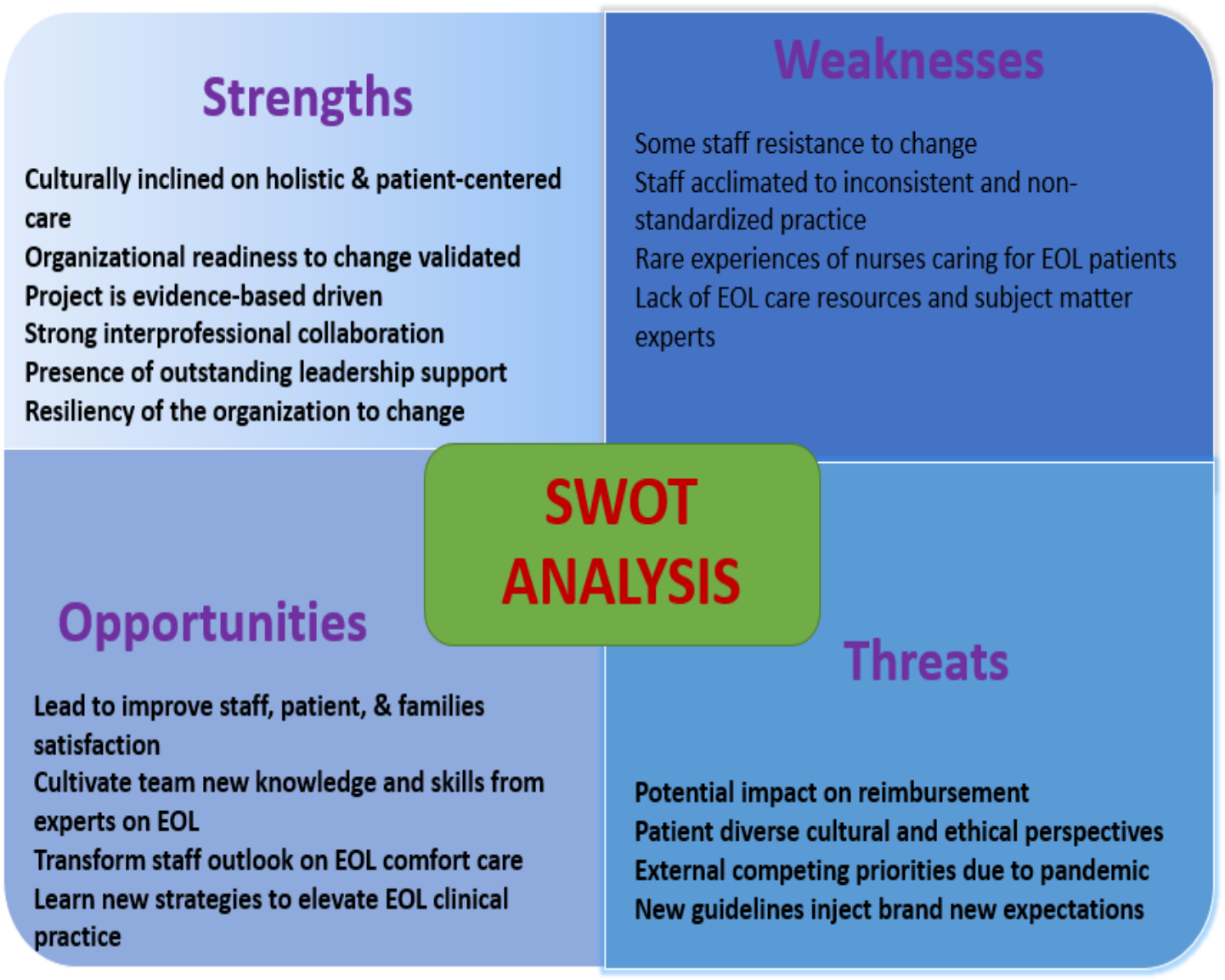


EVIDENCE-BASED END-OF-LIFE COMFORT CARE GUIDELINES

Appendix E

The Patient Dignity Inventory Tool

\section{The Patient Dignity Inventory (PDI)}

For each item, please indicate how much of a problem or concern these have been for you within

the last few days.

$1=$ NOT A PROBLEM

2 = A SLIGHT PROBLEM

$3=A$ PROBLEM

$\mathbf{5}=$ AN OVERWHELMING PROBLEM

1 Not being able to carry out tasks associated with daily living (e.g., washing myself, getting dressed)

2 Not being able to attend to my bodily functions independently (e.g, needing assistance with toileting-related activities)

3 Experiencing physically distressing symptoms (e.g., pain, shortness of breath, nausea)

4 Feeling that how I look to others has changed significantly

5 Feeling depressed

6 Feeling anxious

7 Feeling uncertain about illness and treatment

8 Worrying about my future

9 Not being able to think clearly

10 Not being able to continue with my usual routines

11 Feeling like I am no longer who I was

12 Not feeling worthwhile or valued

13 Note being able to carry out important roles (e.g., spouse, parent)
14 Feeling that life no longer has meaning or purpose

15 Feeling that I am not making a meaningful and/or lasting contribution in my life

16 Feeling that I have "unfinished business" (e.g., things that I have yet to say or do, or that feel incomplete)

17 Concern that my spiritual life is not meaningful

18 Feeling that $\mathrm{I}$ am a burden to others

19 Feeling that I don't have control over my life

20 Feeling that my illness and care needs have reduced my privacy

21 Not feeling supported by my community of friends and family

22 Not feeling supported by my health care providers

23 Feeling like I am no longer able to mentally "fight" the challenges of my illness

24 Not being able to accept the way things are

25 Not being treated with respect or understanding by others 
EVIDENCE-BASED END-OF-LIFE COMFORT CARE GUIDELINES

\title{
Appendix F
}

\section{Department of Nursing}

\section{Nurse's Perception on End-of-Life Comfort Care (EOL) \\ Pre-Survey}

\begin{abstract}
Our goal is to always deliver holistic and patient/family-centered care during the active onset of the patient's EOL. Please take a moment to answer the questions below related to end of life comfort care. I thank you for your participation.

Yrs. of Experience as $\mathrm{n}$ RN: $\square$ Less than $1 \mathrm{yr}$.

$1-5 \mathrm{yrs} . \square \quad \square-10 \mathrm{yrs}$

More than $10 \mathrm{yrs}$

Highest Level of Education: $\square \quad$ ADN $\square \quad$ BSN $\square \quad$ MSN $\square \quad$ DNP

Title: $\square$ RNI $\square$ RNII $\square$ RNIII $\square$ SSN
\end{abstract}

1. Did you receive any previous training specific for EOL comfort care?

Yes No

2. Do you feel that you have adequate confidence to provide EOL care for actively dying patients?
Yes
No (explain reason why?)

3. Do you perceive that the facility has adequate and accessible resources available to provide EOL comfort care? It your answer is no, why?
Yes
No (Explain the reason why?)

4. Do you agree that it will be beneficial to have EOL comfort care guideline accessible for nurses to use for the EOL patient?
Yes
No (Explain the reason why?)

5. Do you think that EOL comfort care guidelines help you provide holistic and patient-centered care for EOL patients?
Yes
No (Explain the reason why?) 
EVIDENCE-BASED END-OF-LIFE COMFORT CARE GUIDELINES

\section{Appendix G}

\section{End-of-Life Comfort Care Guidelines Lesson Plan}

Class Title:

Length:

Target Audience:

Developed by:

Materials Needed:

Objectives:

\section{End-of-Life Comfort Care Guidelines}

1 hour

Licensed staff

Myla Maranan, RN, MSN

Laptop w/ LCD

Power point Presentation

Patient Dignity Inventory (PDI) tool handout

Pointer/Remote

This training has been designed to provide the participants with a review of evidence-based practice on End-of-Life (EOL) comfort care guidelines. This in-service will help the nurses at bedside deliver holistic and patient/family-centered care during the active onset of the patient's endof-life stage.

After this in-service, the participants will be able to:

1. Describe EOL and comfort care

2. Identify common symptoms of EOL and the role of the nurse in managing these symptoms

3. Discuss the basic principle of pain assessment and management at $\mathrm{EOL}$

4. Identify and manage psychosocial issues and concerns during EOL.

5. Emphasize the importance of therapeutic communication at EOL.

6. Recognize the importance of the Patient Dignity Inventory Tool (PDI), and its utilization

7. Identify available resources within the organization in managing EOL patients.

Content Outline:

I. End of Life \& Comfort Care

II.

A. End-of-Life care signifies the realization of the irreversibility of a life-limiting medical condition(s) that will anticipate the result in death.

B. The goal of comfort care is to provide the patient with physical, psychosocial, emotional, 


\section{EVIDENCE-BASED END-OF-LIFE COMFORT CARE GUIDELINES}

and spiritual comfort and help alleviate distress for the family. Comfort care is not intended to hasten or prolong the dying process.

\section{Signs and Symptoms and Management}

\begin{tabular}{|c|c|c|}
\hline $\begin{array}{l}\text { Physiological } \\
\text { Impairment }\end{array}$ & Signs and Symptoms & Nursing Management \\
\hline \multicolumn{3}{|c|}{ Cardiac and Circulation Changes } \\
\hline $\begin{array}{l}\text { Decreased blood } \\
\text { perfusion }\end{array}$ & $\begin{array}{l}\text { - Skin may become mottled } \\
\text { and discolored. Mottling and } \\
\text { cyanosis of the upper } \\
\text { extremities appear to indicate } \\
\text { impending death versus such } \\
\text { changes in the lower } \\
\text { extremities. }\end{array}$ & $\begin{array}{l}\text { - Provide skin care } \\
\text { - Turn patient every 2-3 hours } \\
\text { - Support extremities with soft } \\
\text { pillows }\end{array}$ \\
\hline $\begin{array}{l}\text { Decreased cerebral } \\
\text { perfusion }\end{array}$ & $\begin{array}{l}\text { - Decreased level of } \\
\text { consciousness or terminal } \\
\text { delirium. } \\
\text { - } \text { Drowsiness/disorientation }\end{array}$ & $\begin{array}{l}\text { - } \begin{array}{l}\text { Orient and reorient patient as } \\
\text { needed } \\
\text { - }\end{array} \text { Allow adequate rest periods }\end{array}$ \\
\hline $\begin{array}{l}\text { Decrease in cardiac } \\
\text { output \& intravascular } \\
\text { volume }\end{array}$ & $\begin{array}{l}\text { - } \text { Tachycardia } \\
\text { - } \text { Hypotension } \\
\text { - } \text { Central and peripheral } \\
\text { cyanosis and peripheral } \\
\text { cooling. }\end{array}$ & $\begin{array}{l}\text { - } \text { Comfort measures } \\
\text { - } \text { Space out activities }\end{array}$ \\
\hline \multicolumn{3}{|c|}{ Urinary function } \\
\hline $\begin{array}{l}\text { Decreased urinary } \\
\text { output }\end{array}$ & $\begin{array}{l}\text { - Possible urinary incontinence } \\
\text { - Concentrated urine }\end{array}$ & $\begin{array}{ll}\text { - } & \text { Keep patient clean and dry } \\
\text { - } & \text { Consult with MD for possible } \\
& \text { Foley catheter insertion }\end{array}$ \\
\hline \multicolumn{3}{|c|}{ Nutrition } \\
\hline $\begin{array}{l}\text { Decreased interest in } \\
\text { food and fluid. }\end{array}$ & $\begin{array}{ll}\text { - } & \text { Weight loss } \\
\text { - } & \text { Dehydration }\end{array}$ & $\begin{array}{l}\text { - Do not force fluid or foods } \\
\text { - } \text { Provide excellent mouth care. }\end{array}$ \\
\hline Swallowing difficulties & 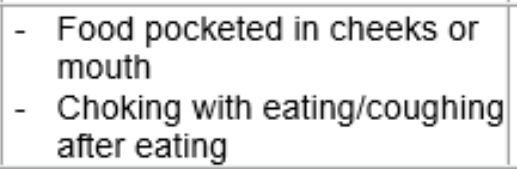 & $\begin{array}{l}\text { - Soft foods and thickened fluids } \\
\text { (e.g. nectar) as tolerated. } \\
\text { - Stop feeding patient if choking or } \\
\text { pocketing food. }\end{array}$ \\
\hline
\end{tabular}




\section{EVIDENCE-BASED END-OF-LIFE COMFORT CARE GUIDELINES}

\begin{tabular}{|c|c|c|}
\hline $\begin{array}{l}\text { Skin may become } \\
\text { mottled or discolored. }\end{array}$ & $\begin{array}{l}\text { - Patches of purplish or dark } \\
\text { pinkish color can be noted on } \\
\text { back and posterior arms/legs. }\end{array}$ & $\begin{array}{l}\text { - Keep sheets clean and dry } \\
\text { - } \text { Apply lotion as tolerated }\end{array}$ \\
\hline \multicolumn{3}{|c|}{ Respiratory } \\
\hline $\begin{array}{l}\text { Retention of secretions } \\
\text { in the pharynx and the } \\
\text { upper respiratory tract. }\end{array}$ & $\begin{array}{l}\text { - Noisy respirations - usually } \\
\text { no cough or weak cough. }\end{array}$ & $\begin{array}{l}\text { - Head of bed up at } 45 \text { degrees. } \\
\text { - Support using soft pillow behind } \\
\text { neck for extra support. }\end{array}$ \\
\hline Dyspnea & - Shortness of breath & - Administer Oxygen as ordered \\
\hline $\begin{array}{l}\text { Cheyne-Stokes } \\
\text { respirations }\end{array}$ & $\begin{array}{l}\text { - Abnormal pattern in } \\
\text { breathing characterized by } \\
\text { progressively deeper \& } \\
\text { faster }\end{array}$ & $\begin{array}{l}\text { - Educate families that this is } \\
\text { normal as the patient is dying. }\end{array}$ \\
\hline
\end{tabular}

\begin{tabular}{|c|c|c|}
\hline $\begin{array}{l}\text { Psychological } \\
\text { Impairment }\end{array}$ & Signs and Symptoms & Nursing Management \\
\hline \multicolumn{3}{|c|}{ Anxiety } \\
\hline $\begin{array}{l}\text { Difficulty concentrating, } \\
\text { Irritability, Irrational } \\
\text { fears }\end{array}$ & $\begin{array}{l}\text { - Restlessness } \\
\text { - Agitation }\end{array}$ & $\begin{array}{l}\text { - Dim the lighting in the room } \\
\text { - Speak softly } \\
\text { - Create a quiet environment } \\
\text { - Use gentle touch } \\
\text { - Acupuncture and guided imagery } \\
\text { with inclusion of relaxation therapy }\end{array}$ \\
\hline \multicolumn{3}{|c|}{ Delirium } \\
\hline $\begin{array}{l}\text { Decreased cognitive } \\
\text { abilities }\end{array}$ & 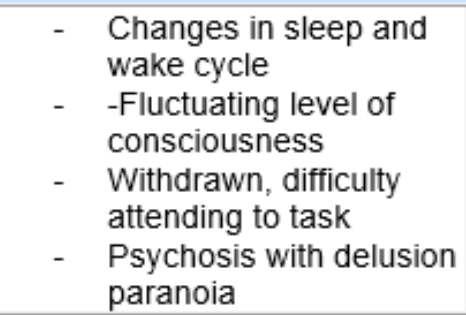 & $\begin{array}{l}\text { - Keep the patient calm and sedated } \\
\text { - Pain medication } \\
\text { - Neuroleptics }\end{array}$ \\
\hline \multicolumn{3}{|c|}{ Depression } \\
\hline Sadness & $\begin{array}{l}\text { - Feeling hopeless \& } \\
\text { Helpless }\end{array}$ & $\begin{array}{l}\text { - Counseling } \\
\text { - Psychostimulants }\end{array}$ \\
\hline
\end{tabular}




\title{
EVIDENCE-BASED END-OF-LIFE COMFORT CARE GUIDELINES
}

\author{
IV. Pain
}

A. Signs and Symptoms of Pain

While several patients can appraise and verbally express their pain levels, other patients can seldom think that acknowledging pain causes them to look weak - which is not accurate. Alzheimer's disease and other dementia make it challenging for individuals to express their needs in separate circumstances. In any case, caregivers should preserve an eye for signs and symptoms that confer their loved one is in pain.

Some of the signs and symptoms to look for include the following:

- Increased breathing rate

- Tightly closed eyes or rapid blinking

- An increase in the patient's systolic blood pressure from their baseline

- Holding arm or leg muscles tightly or a rigid body posture

- Rocking, fidgeting, or pacing

- Resisting care or guarding certain areas of the body when turning

- Becoming withdrawn

- Becoming more aggressive or easily angered

- $\quad$ Crying

- Increased confusion

- Vocalizations such as moaning, calling out, sighing, and asking for help.

B. Pain management

Principles of pain management in hospice should include a recognition that pain is subjective and pain can be controlled at the end of life, and that care should:

- Assess and re-assess pain continually

- Use standardized pain assessment tools- (E.g. CPOT- Critical Care Pain observation tool, Oucher, Numeric scale) 


\section{EVIDENCE-BASED END-OF-LIFE COMFORT CARE GUIDELINES}

- Use "around the clock" analgesics as well as PRN "breakthrough" analgesics

- Include non-pharmaceutical interventions such as diversion, deep breathing exercises, music etc.

- Provide ongoing instructions to patients and families on how to control pain

V. Therapeutic Communication

EOL nursing care should focus on holistic and patient-centered care by addressing the patient and family's spiritual-psychosocial health. Nurses must enable communication with family and significant others to establish the patient's priorities and wishes, supporting them to make informed decisions. It provides an opportunity to explore any anxieties or gaps in the understanding of the situation and foster open and honest communication with the patient/ family.

Following actions will help to improve therapeutic communication:

- Speaks clearly and slowly using simple words that are easy to understand

- Attempt to ask a question using open-ended questions and exercise active listening

- Displays a genuine plan to learn what concerns the patient and patient's families have

- Offer sufficient time accommodating patient and patient's families' questions and concerns

- Communicate and prepare the family for what to expect as the patient's condition deteriorates and should never be underestimated

VI. Culture and Spirituality

Giving appropriate cultural and spiritual support will enhance the positive experience of a patient who is on verge of dying by:

- Being mindful of patient's values and beliefs 


\section{EVIDENCE-BASED END-OF-LIFE COMFORT CARE GUIDELINES}

- Accommodate any religious rituals that may assist the patient and family before passing

- If needed, provide all necessary resources (e.g. Chaplain) available support the spiritual needs further

- Have open communication and be non-judgmental

VII. The Patient Dignity Inventory Tool (PDI)

The PDI tool is a simple, open-ended questionnaire designed to identify stressors that may be important to consider when planning and delivering care for patients who is on the verge of dying. The PDI tool comprises of 25 questions/ indicators. Each question is based on evidence-based principles regarding the most common factors influencing people's personal sense of dignity. For each factor, the person indicates his/her degree of concern on a five-point scale, with 1 representing "not a problem" and 5 representing "an overwhelming problem."

If the patient is identified to be on the EOL stage, utilize the EOL guidelines using the PDI tool to determine the appropriate plan of care within 24 hours of patient needing EOL care. The plan of care is initiated if the patient's score on the problem indicators is 3 and above.

VIII. End of Life Guidelines using PDI tool

\begin{tabular}{|c|c|c|}
\hline Domains & Problem Indicators & Interventions \\
\hline \multirow[b]{2}{*}{ Physical } & $\begin{array}{l}\text { - Not being able to carry out } \\
\text { tasks associated with daily } \\
\text { living (e.g., washing self, } \\
\text { getting dressed) }\end{array}$ & \multirow{2}{*}{$\begin{array}{l}\text { - Conduct baseline and } \\
\text { ongoing assessment of } \\
\text { symptoms } \\
\text { - Comfort care } \\
\text { - Assist with ADLs as needed } \\
\text { - Involve family } \\
\text { - Pharmacological } \\
\text { interventions }\end{array}$} \\
\hline & $\begin{array}{l}\text { - Not being able to attend to } \\
\text { my bodily functions } \\
\text { independently (e.g., needing } \\
\text { assistance with toileting- } \\
\text { related activities) }\end{array}$ & \\
\hline
\end{tabular}




\section{EVIDENCE-BASED END-OF-LIFE COMFORT CARE GUIDELINES}

\begin{tabular}{|c|c|c|}
\hline & $\begin{array}{l}\text { Experiencing physically } \\
\text { distressing symptoms (e.g., } \\
\text { pain, shortness of breath, } \\
\text { nausea) }\end{array}$ & $\begin{array}{l}\text { - Non-pharmacological } \\
\text { interventions (positioning, } \\
\text { guided imagery, etc.) } \\
\text { - Provide assistive devices to } \\
\text { maintain independence } \\
\text { (e.g., walker, raised toilet } \\
\text { seat) } \\
\text { - Oxygen therapy } \\
\text { - Consult with Pain and } \\
\text { Palliative nurse }\end{array}$ \\
\hline \multirow[t]{17}{*}{ Psychological } & $\begin{array}{l}\text { - Feeling that how I look to } \\
\text { others has changed } \\
\text { significantly }\end{array}$ & \multirow{17}{*}{ 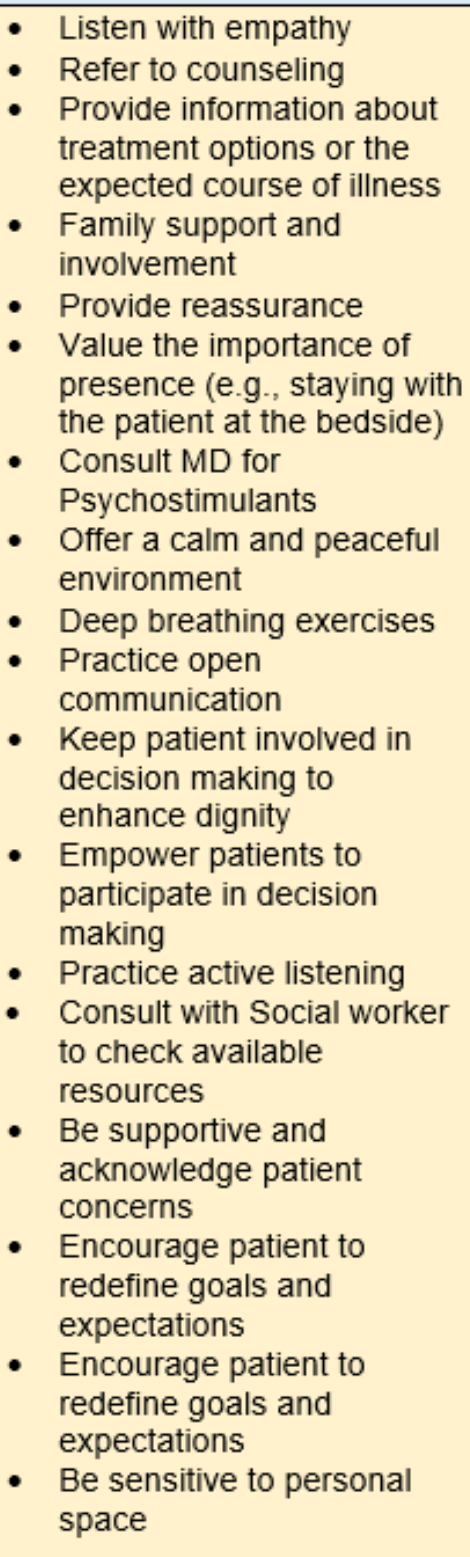 } \\
\hline & - Feeling depressed & \\
\hline & - Feeling anxious & \\
\hline & $\begin{array}{l}\text { - Feeling uncertain about } \\
\text { illness and treatment }\end{array}$ & \\
\hline & - Not being able to think clearly & \\
\hline & $\begin{array}{l}\text { - Not being able to continue } \\
\text { with my usual routines }\end{array}$ & \\
\hline & $\begin{array}{l}\text { - Feeling like I am no longer } \\
\text { who I was }\end{array}$ & \\
\hline & $\begin{array}{l}\text { - Not feeling worthwhile or } \\
\text { valued }\end{array}$ & \\
\hline & $\begin{array}{l}\text { - Not being able to carry out } \\
\text { important roles (e.g., spouse, } \\
\text { parent) }\end{array}$ & \\
\hline & $\begin{array}{l}\text { Feeling that life no longer } \\
\text { has meaning or purpose }\end{array}$ & \\
\hline & $\begin{array}{l}\text { - Feeling that I am not making } \\
\text { a meaningful and/or lasting } \\
\text { contribution in my life }\end{array}$ & \\
\hline & $\begin{array}{l}\text { - Feeling that I have } \\
\text { "unfinished business" (e.g., } \\
\text { things that I have yet to say } \\
\text { or do, or that feel incomplete) }\end{array}$ & \\
\hline & $\begin{array}{l}\text { - Feeling that I am a burden to } \\
\text { others }\end{array}$ & \\
\hline & $\begin{array}{l}\text { - Feeling that I don't have } \\
\text { control over my life }\end{array}$ & \\
\hline & $\begin{array}{l}\text { - Feeling that my illness and } \\
\text { care needs have reduced my } \\
\text { privacy }\end{array}$ & \\
\hline & $\begin{array}{l}\text { - Feeling like I am no longer } \\
\text { able to mentally "fight" the } \\
\text { challenges of my illness }\end{array}$ & \\
\hline & $\begin{array}{l}\text { - Not being able to accept the } \\
\text { way things are }\end{array}$ & \\
\hline
\end{tabular}




\section{EVIDENCE-BASED END-OF-LIFE COMFORT CARE GUIDELINES}

\begin{tabular}{|c|c|c|}
\hline & & 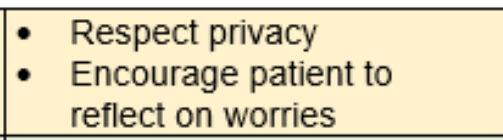 \\
\hline \multirow[t]{3}{*}{ Social } & $\begin{array}{l}\text { - Not feeling supported by my } \\
\text { community of friends and } \\
\text { family }\end{array}$ & \multirow{3}{*}{$\begin{array}{l}\text { - Provide patient and family } \\
\text { support } \\
\text { - Social work consult } \\
\text { - Acknowledge patient } \\
\text { concerns } \\
\text { - Provide resources such as } \\
\text { Patient advocate } \\
\text { - Encourage the involvement } \\
\text { of family }\end{array}$} \\
\hline & $\begin{array}{l}\text { - Not feeling supported by my } \\
\text { health care providers }\end{array}$ & \\
\hline & $\begin{array}{l}\text { Not being treated with } \\
\text { respect or understanding by } \\
\text { others }\end{array}$ & \\
\hline $\begin{array}{l}\text { Spiritual \& } \\
\text { Religious }\end{array}$ & $\begin{array}{l}\text { - Concern that my spiritual life } \\
\text { is not meaningful }\end{array}$ & 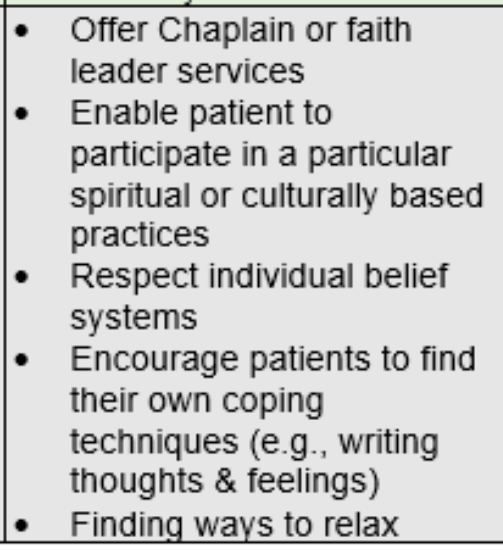 \\
\hline
\end{tabular}

\section{Other Resources}

- Certified Pain and Palliative Care Registered Nurse Consultant

- Bio-ethics committee

- Risk Management

- Patient Advocate

- Psychologist 


\section{EVIDENCE-BASED END-OF-LIFE COMFORT CARE GUIDELINES}

\section{References}

Carvajal, A., Haraldsdottir, E., Kroll, T., McCormack, B., Errasti-Ibarrondo, B., \& Larkin, P. (2019). Barriers and facilitators perceived by registered nurses in providing personcentered care at the end of life. A scoping review. International Practice Development Journal, 9(2), 1-22. https://doi.org/10.19043/ipdj.92.008

Caton, A. P., \& Klemm, P. (2006). Introduction of novice oncology nurses to end-of-life care. Clinical Journal of Oncology Nursing, 10(5), 604-8. Retrieved from https: $/ /$ search.proquest.com/docview $/ 222747919$ ?accountid $=45853$

Chochinov, H. M., Hassard, T., McClement, S., Hack, T., Kristjanson, L. J., Harlos! M., Sinclair, S., \& Murray, A. (2008). The patient dignity Inventory: A novel way of measuring dignity-related distress in palliative care. Journal of Pain and Symptom Management, 36(6), 559-571. https://doi.org/10.1016/j.jpainsymman.2007.12.018.

Henry, B. (2020). End of life feeding: Ethical and legal considerations. Physiology \& Behavior, 217. https://doi.org/10.1016/j.physbeh.2020.112800

Hermann, C., \& Looney, S. W. (2011). Determinants of quality of life in patients near the end of life: A longitudinal perspective. Oncology Nursing Forum, 38(1), 23-31. https: $/ /$ search.proquest.com/docview/822930967?accountid $=45853$

Kelly, B. McClement, S. \& Chochinov H. M. (2006). Measurement of psychological distress in palliative care. Palliative Medicine, 20(8), 779-789.

Matzo, M. F., \& Sherman, W. D. (2015). Palliative Care Nursing: Quality Care to the End of Life: Vol. Fourth edition. Springer Publishing Company. 


\section{EVIDENCE-BASED END-OF-LIFE COMFORT CARE GUIDELINES}

Murillo, M. I., \& Holland, J. C. (2004). Clinical practice guidelines for the management of psychosocial distress at the end of life. Palliative \& Supportive Care, 2(1), 65-77. https: $/ /$ search.proquest.com/docview $/ 214842410$ ?accountid $=45853$

Rancho Los Amigos National Rehabilitation Center Administrative Policy: Caring of the dying. (2018).

Price, D. M., Strodtman, L., Montagnini, M., Smith, H. M., Miller, J., Zybert, J., . . Ghosh, B. (2017). Palliative and end-of-life care education needs of nurses across inpatient care settings. The Journal of Continuing Education in Nursing, 48(7), 329-336. http: $/ /$ dx.doi.org/10.3928/00220124-20170616-10

Raijmakers, N. J. H., van Zuylen, L., Costantini, M., Caraceni, A., Clark, J. B., De Simone, G., . .. van der Heide, A. (2012). Issues and needs in end-of-life decision making an international modified delphi study. Palliative Medicine, 26(7), 947-53. http: $/ /$ dx.doi.org/10.1177/0269216311423794

Rancho Los Amigos National Rehabilitation Center Administrative Policy: End of Life. (2020).

Strech, D., \& Schildmann, J. (2011). Quality of ethical guidelines and ethical content in clinical guidelines: The example of end-of-life decision-making. Journal of Medical Ethics, 37(7), 390. http://dx.doi.org/10.1136/jme.2010.040121 
EVIDENCE-BASED END-OF-LIFE COMFORT CARE GUIDELINES

\section{Appendix H \\ Nurse's EOL Comfort Care Validation Test and Answers}

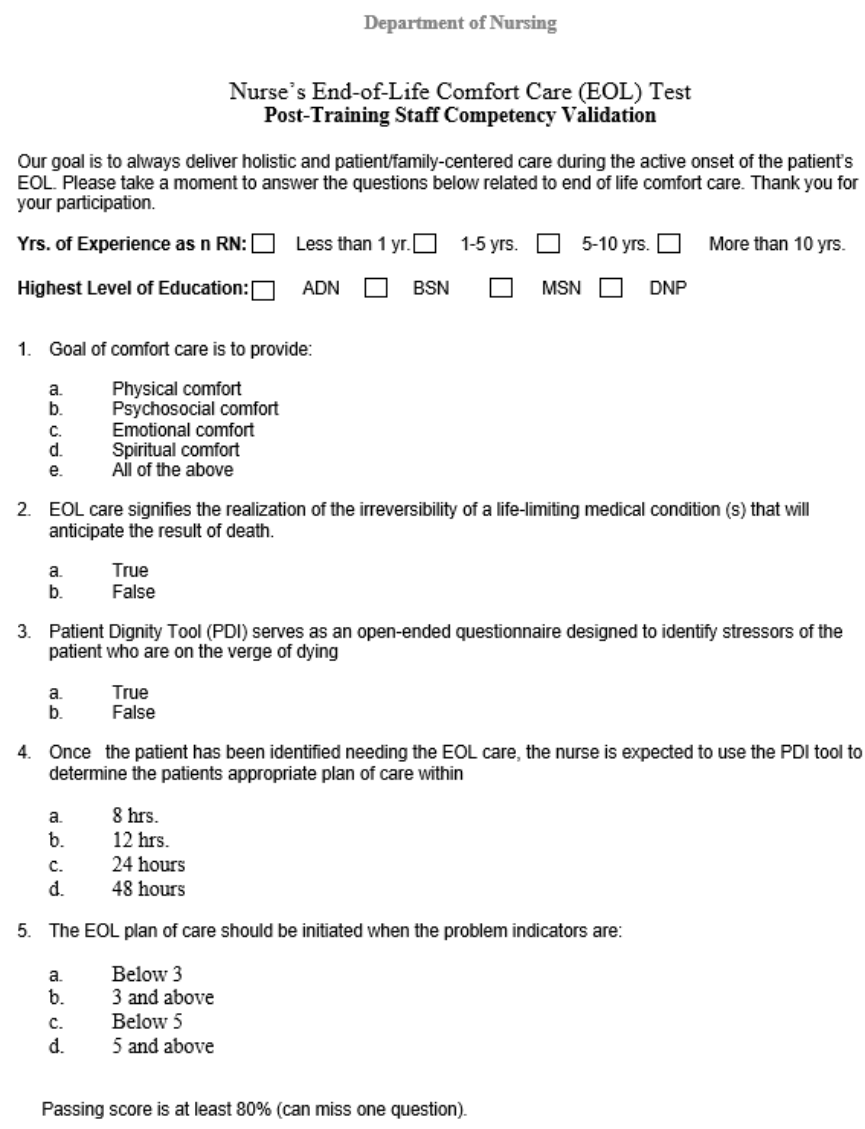

3. Patient Dignity Tool (PDI) serves as an open-ended questionnaire designed to identify stressors of the patient who are on the verge of dying

4. Once the patient has been identified needing the EOL care, the nurse is expected to use the PDI tool to determine the patients appropriate plan of care within

a. $8 \mathrm{hrs}$.

b. $12 \mathrm{hrs}$.

c. 24 hours

d. 48 hours

5. The EOL plan of care should be initiated when the problem indicators are:

$\begin{array}{ll}\text { a. } & \text { Below } 3 \\ \text { b. } & 3 \text { and above } \\ \text { c. } & \text { Below 5 } \\ \text { d. } & 5 \text { and above }\end{array}$

Passing score is at least $80 \%$ (can miss one question). 


\section{EVIDENCE-BASED END-OF-LIFE COMFORT CARE GUIDELINES}

\section{Appendix I}

\section{End-of-Life Comfort Care Guidelines}

\section{End-of-Life Comfort Care Guidelines}

Once the patient is identified to be on the End-of-Life (EOL) stage, complete this PDI tool within 24 hours. For each statement below, the patient indicates his/her degree of concern. If the patient scores 3 (a problem) or above, identify appropriate interventions according to the guidelines.

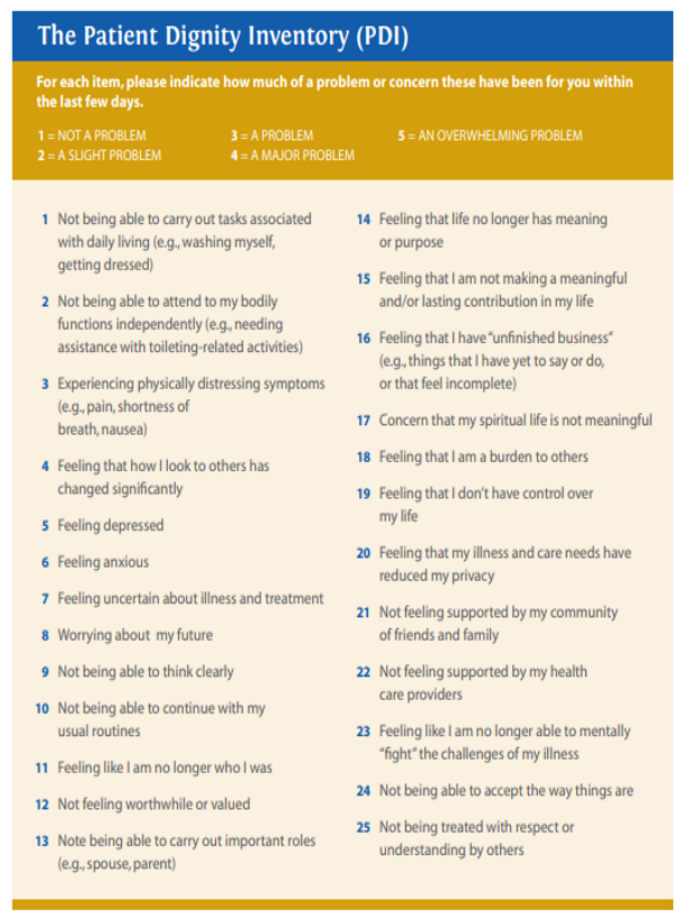

End-of-Life Comfort Care Guidelines

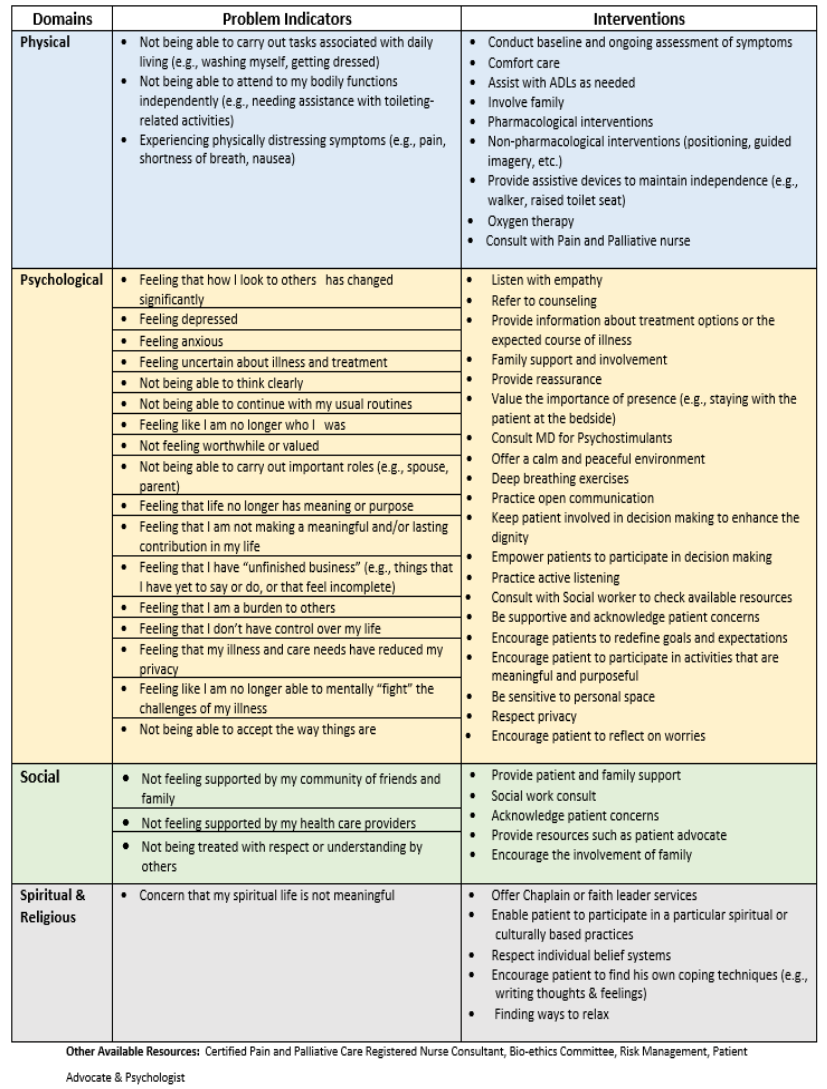


EVIDENCE-BASED END-OF-LIFE COMFORT CARE GUIDELINES

Appendix J

EOL Comfort Care Guidelines PowerPoint Materials
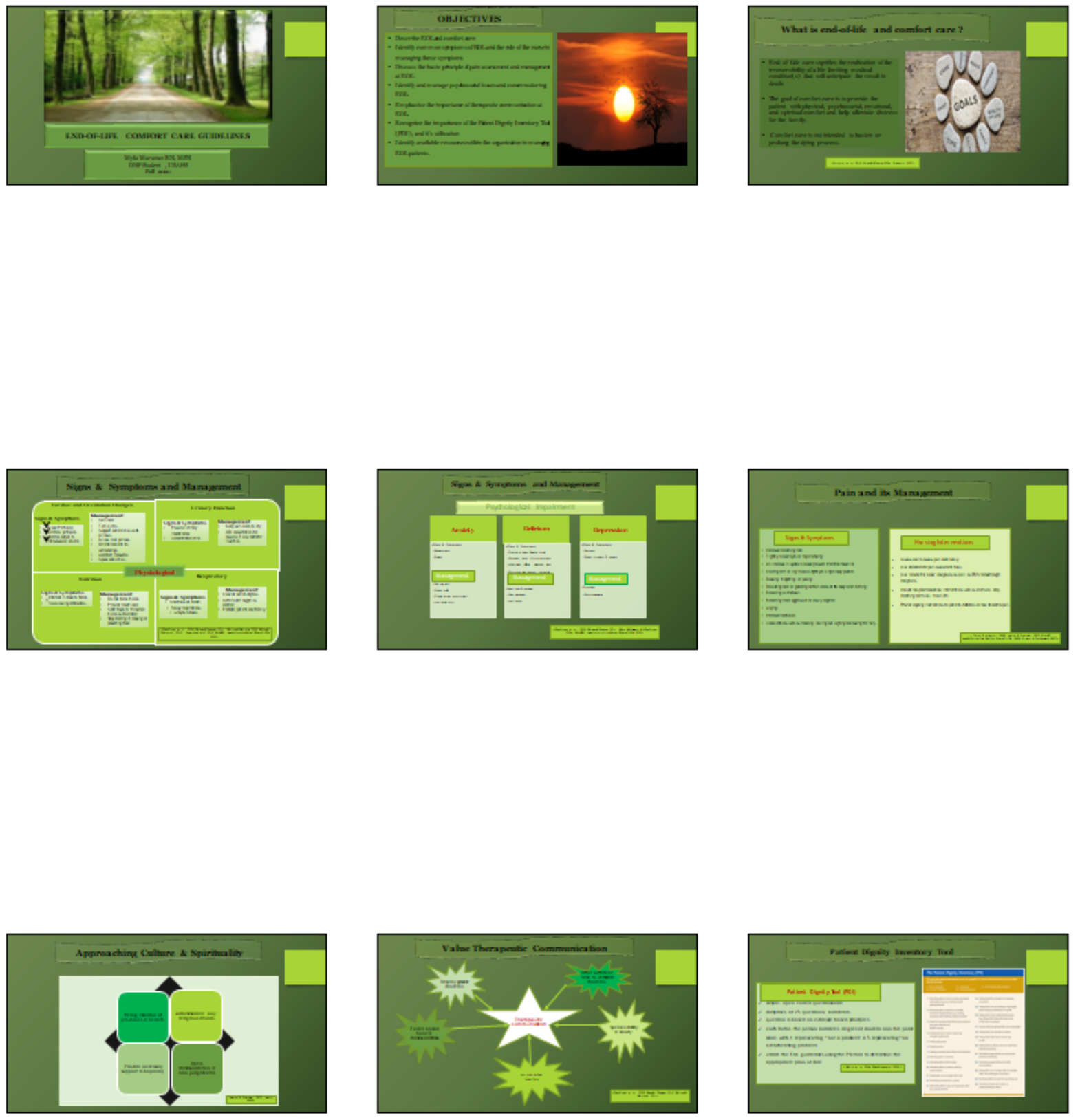
EVIDENCE-BASED END-OF-LIFE COMFORT CARE GUIDELINES
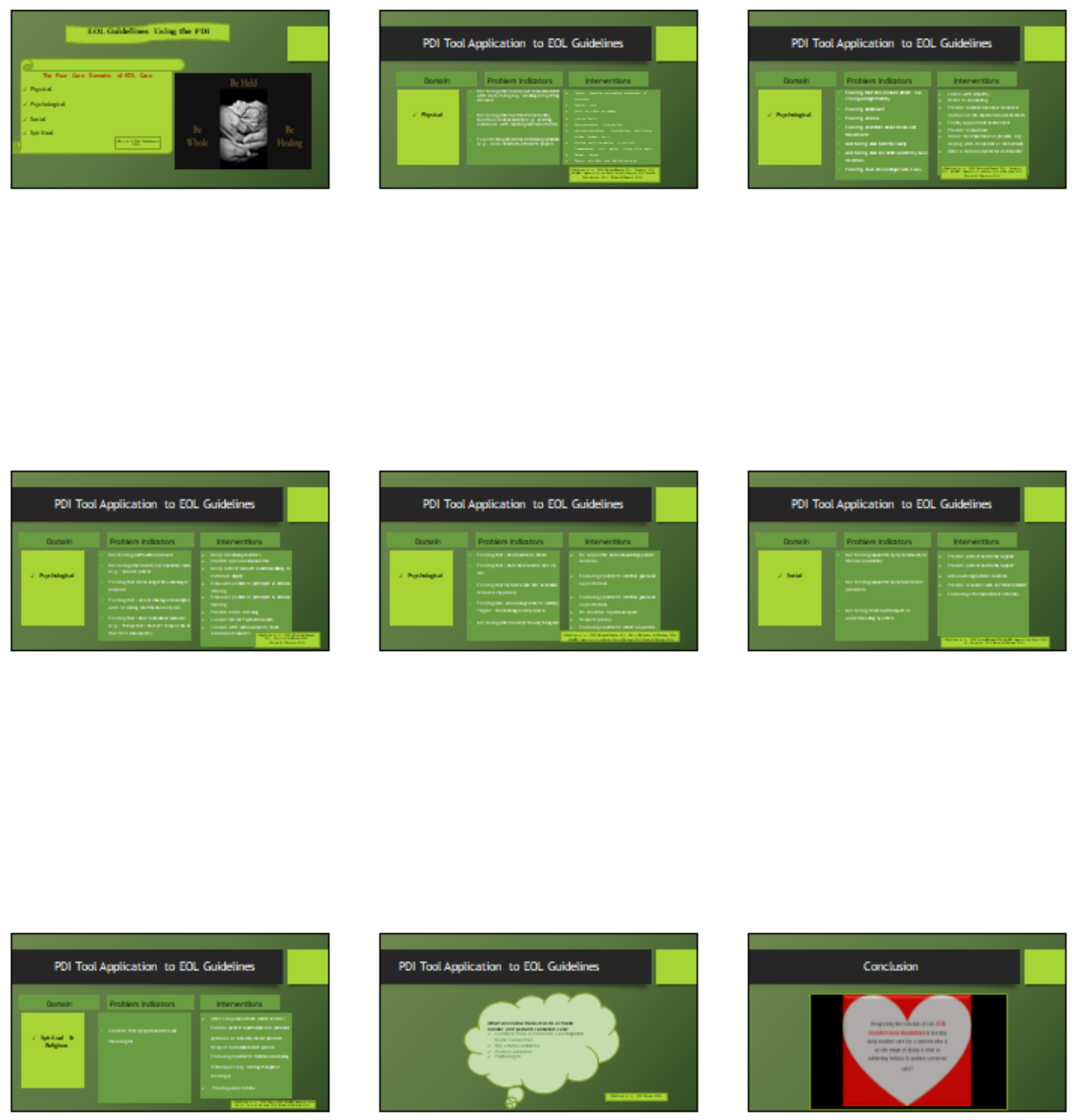
EVIDENCE-BASED END-OF-LIFE COMFORT CARE GUIDELINES
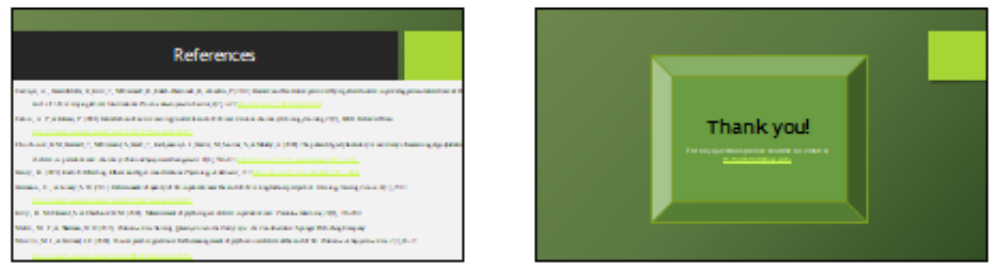
EVIDENCE-BASED END-OF-LIFE COMFORT CARE GUIDELINES

\section{Appendix K}

\section{End-of-Life Comfort Care Guideline Flyer In-service}

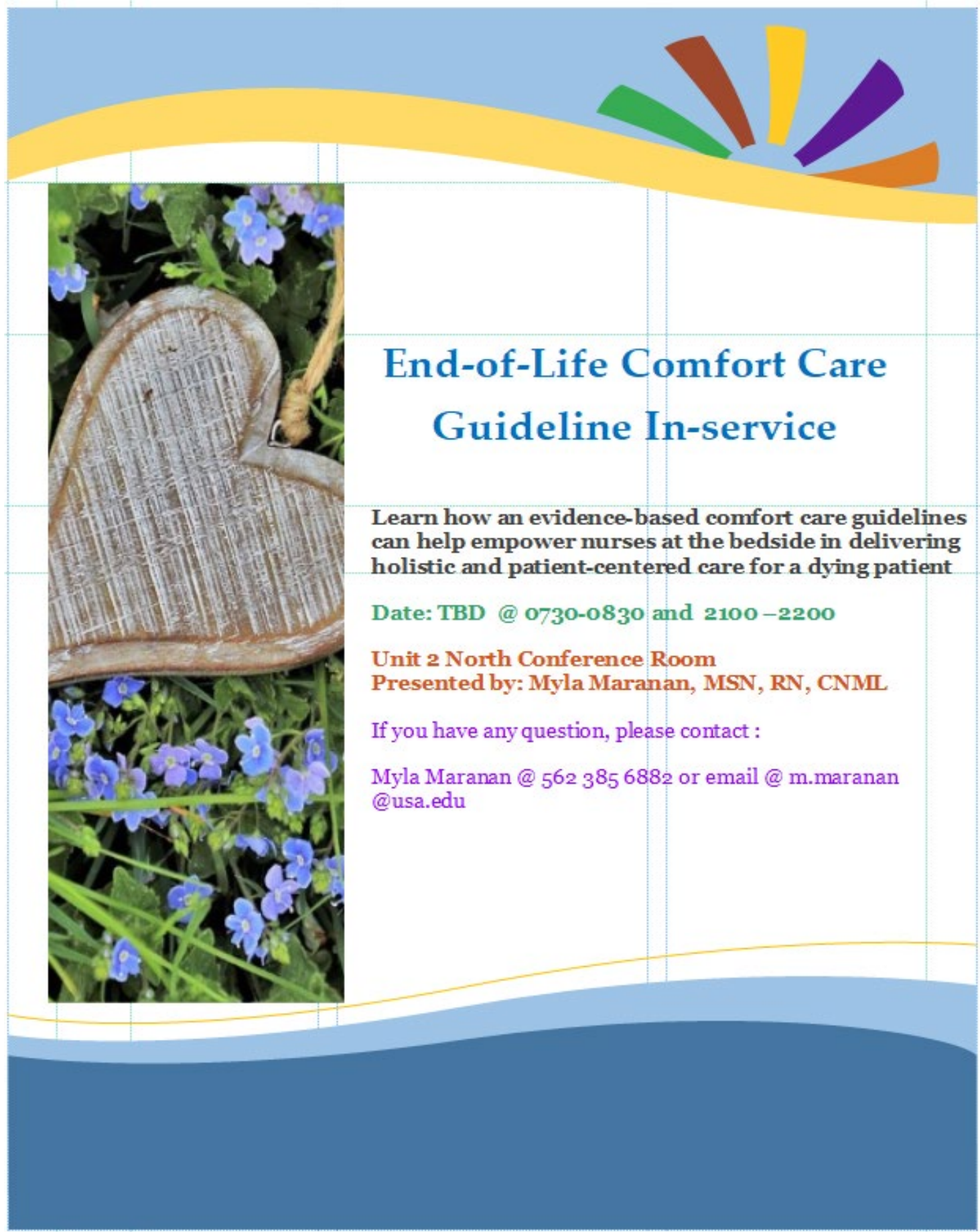




\section{EVIDENCE-BASED END-OF-LIFE COMFORT CARE GUIDELINES}

\section{Appendix L}

\section{EOL CCGs In-Service Roster}

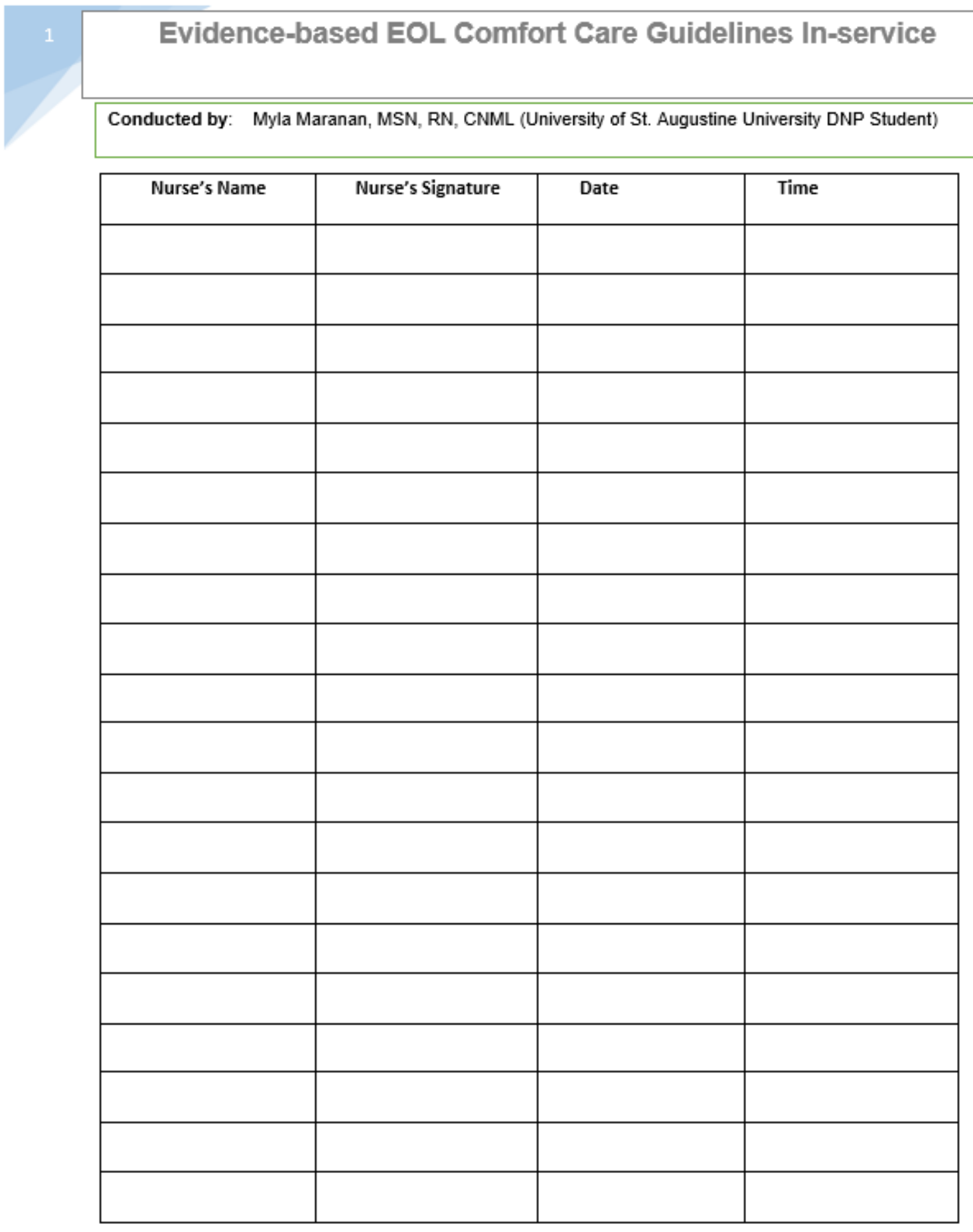




\title{
EVIDENCE-BASED END-OF-LIFE COMFORT CARE GUIDELINES
}

\section{Appendix M}

\author{
End-of-Life Comfort Care Guidelines Audit Tool
}

Patient's Diagnosis:

Patient's Identifier Number:

Age: $\square 25$ - 35 years $\square$ 35- 45 years $\square$ 45- 55 years $\square$ Above 55 years

Gender: $\square$ Male $\square$ Female

\begin{tabular}{|c|c|c|c|}
\hline Criteria & Yes & No & N/A \\
\hline $\begin{array}{l}\text { - Did the nurse utilize the PDI tool for patients who are identified to be on } \\
\text { EOL within } 24 \text { hours? }\end{array}$ & & & \\
\hline $\begin{array}{l}\text { - Did the nurse identify the appropriate EOL problems within the domain } \\
\text { (physical, psychological, social, spiritual \& religious) based on the total } \\
\text { problem scores? }\end{array}$ & & & \\
\hline $\begin{array}{l}\text { - Did the nurse initiate the appropriate plan of care on the EOL comfort care } \\
\text { guidelines for a patient with a problem score of three or above? }\end{array}$ & & & \\
\hline $\begin{array}{l}\text { - Did the nurse initiate the appropriate interventions according to the } \\
\text { identified problems with in the domain (physical, psychological, social, } \\
\text { spiritual \& religious)? }\end{array}$ & & & \\
\hline $\begin{array}{l}\text { - Did the nurse assess the patient's change in condition and complete a new } \\
\text { PDI tool if needed? }\end{array}$ & & & \\
\hline
\end{tabular}




\title{
EVIDENCE-BASED END-OF-LIFE COMFORT CARE GUIDELINES
}

\section{Appendix N}

\author{
Department of Nursing \\ Nurse's Perception on End-of-Life Comfort Care (EOL) \\ Post-Survey
}

\begin{abstract}
Our goal is to always deliver holistic and patient/family-centered care during the active onset of the patient's EOL. Please take a moment to answer the questions below related to end of life comfort care. I thank you for your participation.

Yrs. of Experience as n RN:

Less than $1 \mathrm{y}$.

$1-5$ yrs.

$5-10 \mathrm{yrs}$

More than $10 \mathrm{yrs}$.

Highest Level of Education:

ADN $\square$ BSN

MSN

DNP

Title:

$\square$ RNI

$\square$ RNII

RNIII

SSN

|

1. Did you receive any previous training specific for EOL comfort care?

Yes

No
\end{abstract}

2. Do you feel that you have adequate confidence to provide EOL care for actively dying patients?

Yes

No (explain reason why?)

3. Do you perceive that the facility has adequate and accessible resources available to provide EOL comfort care? It your answer is no, why?

Yes

No (Explain the reason why?)

4. Do you agree that it will be beneficial to have EOL comfort care guideline accessible for nurses to use for the EOL patient?

Yes

No (Explain the resson why?)

5. Do you think that EOL comfort care guidelines help you provide holistic and patient-centered care for EOL patients?

Yes

No (Explain the reason why?) 
EVIDENCE-BASED END-OF-LIFE COMFORT CARE GUIDELINES

\section{Appendix O}

\section{Gantt Chart}

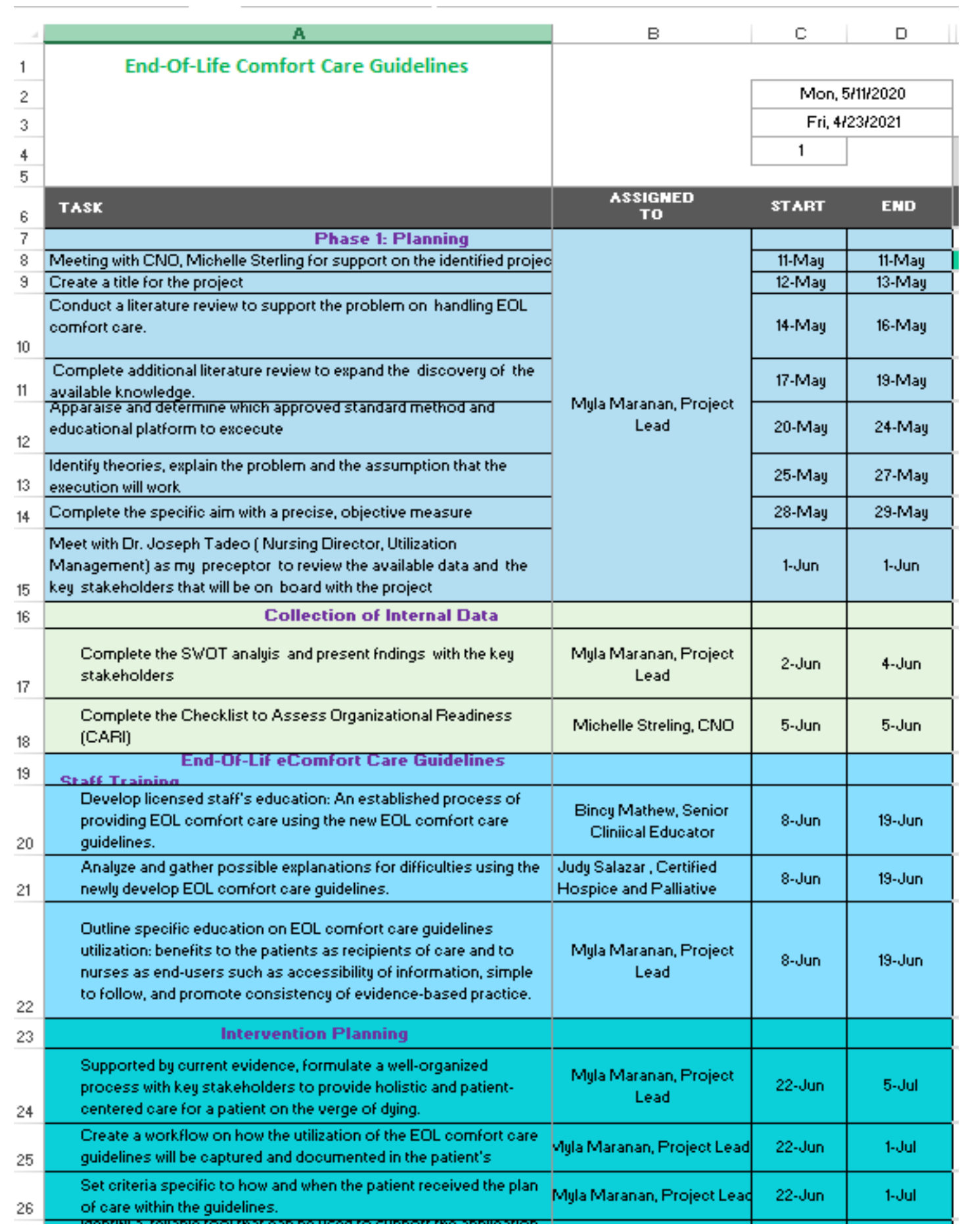




\section{EVIDENCE-BASED END-OF-LIFE COMFORT CARE GUIDELINES}

\begin{tabular}{|c|c|c|c|c|}
\hline 2 & A & $\mathrm{B}$ & $\mathrm{C}$ & $\mathrm{D}$ \\
\hline 27 & $\begin{array}{l}\text { of the EOL guidelines suhc as the Patient Dignity Inventory (PDI) } \\
\text { taol }\end{array}$ & Myla Maranan, Project Lead & 22-Jun & 1-Jul \\
\hline 28 & $\begin{array}{l}\text { Identify unit champions who will help obtain the buy-in and } \\
\text { engagement of the staff, including sustainability of the EOL }\end{array}$ & Medical-Surgical Staff & 6-Jul & 8-Jul \\
\hline 29 & Measures to Eramination & & & \\
\hline 30 & Possible ethical concerns and how to address when recognize & \multirow{5}{*}{$\begin{array}{c}\text { Myla Maranan, Project } \\
\text { Lead }\end{array}$} & 6-Jul & 13-Jul \\
\hline 31 & $\begin{array}{l}\text { Define the outcome measurements and validitgrellabinty for each } \\
\text { messure }\end{array}$ & & 14-Jul & 18-Jul \\
\hline 32 & Monitor each intervention for accuracy and completion & & 19-Jul & 24-Jul \\
\hline 33 & Discover quantitative approaches for each method & & 25-Jul & 29-Jul \\
\hline 34 & Determine methods to comprehend variation within the data & & $30-$ Jul & 3-Aug \\
\hline 35 & $\begin{array}{r}\text { Project Approval } \\
\end{array}$ & & & \\
\hline 36 & Acquire approval from the University of St. Augustine & $\begin{array}{l}\text { Myla Maranan, Project } \\
\text { Lead }\end{array}$ & 9-0et & 12-0ct \\
\hline 37 & $\begin{array}{l}\text { Obtain initial approval from Rancho Los Amigos Evidence-Based } \\
\text { Practice Council }\end{array}$ & $\begin{array}{l}\text { Myla Maranan, Project } \\
\text { Lead }\end{array}$ & $13-0 \mathrm{ctt}$ & 15-0et \\
\hline 38 & Phase 2: Implementation & & & \\
\hline 39 & \multicolumn{2}{|c|}{ Seek final approval from Rancho Los Amigos Nurse Executive CouncilMyla Maranan, Project Lea } & $16-0 \mathrm{ct}$ & $19-0 \mathrm{ct}$ \\
\hline 40 & Key stakeholders approval of the project & $\begin{array}{l}\text { Myla Maranan, Project } \\
\text { Lead }\end{array}$ & $20-0 \mathrm{ct}$ & $21-0 \mathrm{ct}$ \\
\hline 41 & Budget approval specifife for staff training & $\begin{array}{l}\text { Sotera de Los Santos, } \\
\text { Medical-Surgical Nurse } \\
\text { Manager }\end{array}$ & $22-0 \mathrm{ct}$ & $23-0 \mathrm{ct}$ \\
\hline 42 & Staff training $\&$ competency validation & $\begin{array}{l}\text { Bincy Mathew, Senior } \\
\text { Cliniical Educator }\end{array}$ & $26-0 \mathrm{ct}$ & $29-0 \mathrm{ct}$ \\
\hline 43 & Identify the completion rate of education from licensed staff & $\begin{array}{l}\text { Myla Maranan, Project } \\
\text { Lead }\end{array}$ & $29-0 \mathrm{ct}$ & $30-0 \mathrm{ct}$ \\
\hline 44 & Project Implementation & & & \\
\hline 45 & Application of new EOL comfort care guidelines into practice & Bedside RNs & 1-Nov & 30 -Dec \\
\hline 46 & Weekly monitoring of the EOL comfort care guidelines initiatives & $\begin{array}{l}\text { Myla Maranan, Project } \\
\text { Lead }\end{array}$ & 6-Nov & $30-$-Dec \\
\hline 47 & $\begin{array}{l}\text { Data collection every other week for barriers and solutions } \\
\text { identifiod }\end{array}$ & $\begin{array}{l}\text { Myla Maranan, Project } \\
\text { Lead }\end{array}$ & 6-Nov & $30-$-Dec \\
\hline 48 & $\begin{array}{l}\text { Interdisciplinary team full support with the process and assist in } \\
\text { providing holistic and patient-centered care for a patient on the } \\
\text { verge of dying. }\end{array}$ & All stakeholders & 1-Nov & $30-$-Dec \\
\hline 49 & Data & & & \\
\hline 50 & $\begin{array}{l}\text { Pre-survey data collection of the nurses' pereception using the } \\
\text { "Nurses Perception of End- of- Life Comfort Care "tool }\end{array}$ & $\begin{array}{l}\text { Myla Maranan, Project } \\
\text { Lead \& Unit Champions }\end{array}$ & 26-0et & $29-0 \mathrm{ct}$ \\
\hline 51 & $\begin{array}{l}\text { Post-survey data collection of the nurses' perception using the } \\
\text { "Nurse's Perception of End-of-Life Comfort Care "tool }\end{array}$ & $\begin{array}{l}\text { Myla Maranan, Project } \\
\text { Lead \& Unit Champions }\end{array}$ & 30 -Dec & 31-Dec \\
\hline 52 & $\begin{array}{l}\text { Data collection via chart reviews using the "End-of-Life Comfort } \\
\text { Care Guidelines Audit Tool" }\end{array}$ & $\begin{array}{l}\text { Myla Maranan, Project } \\
\text { Lead }\end{array}$ & 6-Nov & $30-$-Dec \\
\hline 53 & $\begin{array}{l}\text { Medical-Surgical licensed nurses' weekly feedback: limitations and } \\
\text { solutions }\end{array}$ & $\begin{array}{l}\text { Myla Maranan, Project } \\
\text { Lead \& Unit Champions }\end{array}$ & 6-Nov & 30 -Dec \\
\hline 54 & $\begin{array}{c}\text { Phase 3: Evaluation } \\
\end{array}$ & & & \\
\hline 55 & Results & & & \\
\hline 56 & & & & \\
\hline 57 & Summary & & & \\
\hline 58 & Summary of critical findings, significance to the rationale, and the pu & urpose & & \\
\hline 59 & Examine and discuss the strengths of the project with the interprofe: & ssional team & & \\
\hline 60 & & & & \\
\hline 61 & & & & \\
\hline 62 & Celebrate Sucess! & & 5-Jan & 5-Jan \\
\hline 63 & & & & \\
\hline
\end{tabular}


EVIDENCE-BASED END-OF-LIFE COMFORT CARE GUIDELINES

\section{Appendix P}

Forecasted Project Budget Expenses

\begin{tabular}{|l|l|l|l|}
\hline \multicolumn{1}{|c|}{$\begin{array}{c}\text { Medical-Surgical Project Team } \\
\text { Member Participants }\end{array}$} & Hour/Unit & \multicolumn{1}{|c|}{$\begin{array}{c}\text { Hourly Salary } \\
\text { Rate }\end{array}$} & Total Cost \\
\hline Full-time Registered Nurse (Total=30) & 1 hour & $\$ 45.00$ & $\$ 1,350.00$ \\
\hline Relief Registered Nurse (Total=10) & 1 hour & $\$ 60.00$ & $\$ 600.00$ \\
\hline Unit Clinical Educator & 3 hours & $\$ 68.00$ & $\$ 204.00$ \\
\hline Unit Nurse Manager & 3 hours & salary & $\$ 0$ \\
\hline $\begin{array}{l}\text { Assistant Nurse Managers (total =2) } \\
\text { (Designated Unit Champions) }\end{array}$ & 3 hours & $\$ 73.00$ & $\$ 438.00$ \\
\hline Nurse Informatics & 2 hours & $\$ 58.00$ & $\$ 116.00$ \\
\hline Information Technology & 2 hours & $\$ 40.00$ & $\$ 80.00$ \\
\hline $\begin{array}{l}\text { Miscellaneous Expenses (stationary } \\
\text { materials) }\end{array}$ & & & $\$ 50.00$ \\
\hline Total Operating Expenses & & & $\$ 2,838.00$ \\
\hline
\end{tabular}




\section{EVIDENCE-BASED END-OF-LIFE COMFORT CARE GUIDELINES}

\section{Appendix Q}

\section{PDI Usage Authorization}

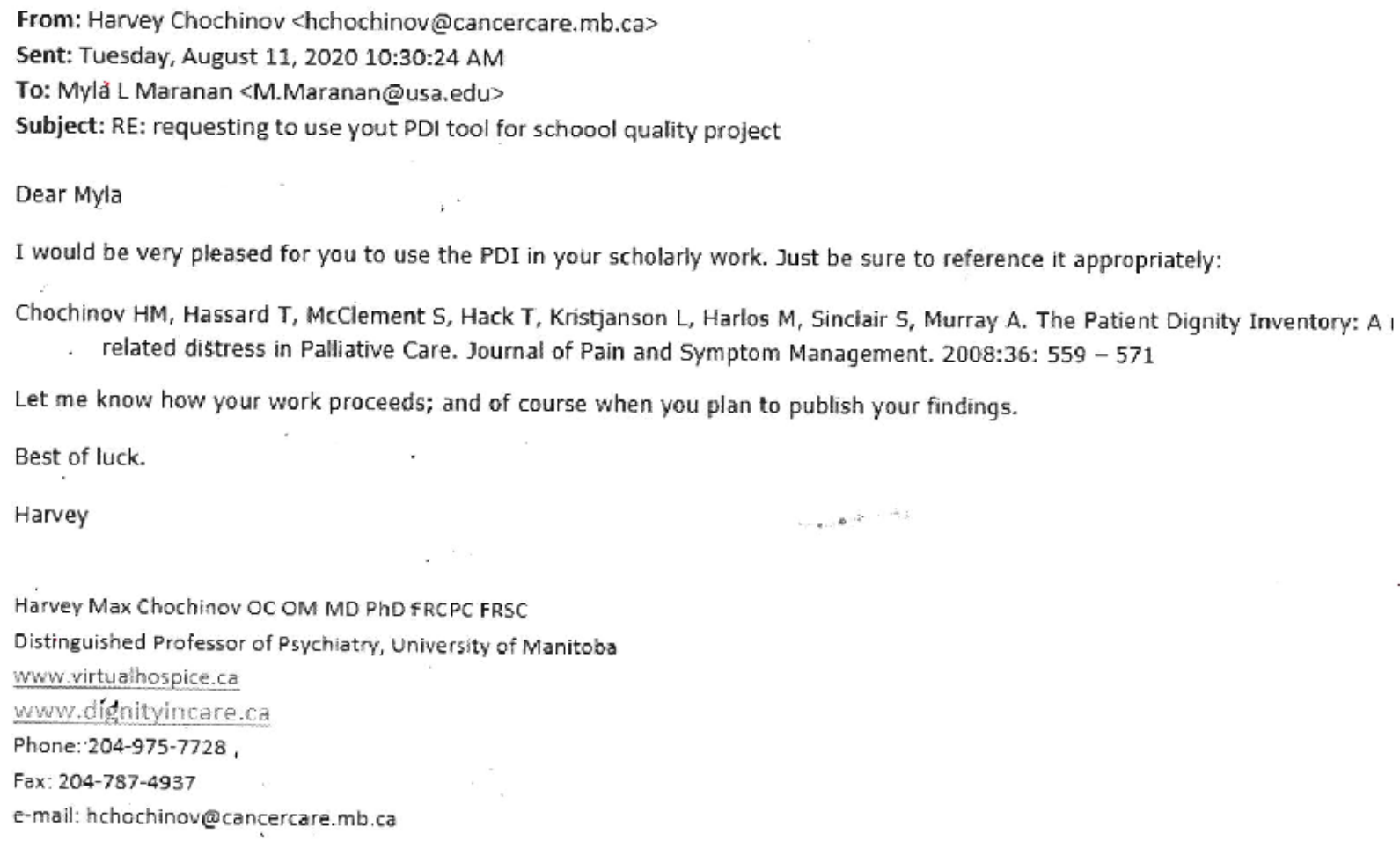


EVIDENCE-BASED END-OF-LIFE COMFORT CARE GUIDELINES

\section{Appendix R}

\section{Project Implementation PDI Responses}

PDI Responses $(N=4)$

\begin{tabular}{|c|c|c|c|c|}
\hline Item & Min & Max & $M$ & $S D$ \\
\hline $\begin{array}{l}\text { Not being able to carry out tasks associated with daily living (e.g., } \\
\text { washing myself, getting dressed) }\end{array}$ & 3.00 & 3.00 & 3.00 & .00 \\
\hline $\begin{array}{l}\text { Not being able to attend to my bodily functions independently (e.g-, } \\
\text { needing assistance with toileting-related activities) }\end{array}$ & 3.00 & 3.00 & 3.00 & .00 \\
\hline $\begin{array}{l}\text { Experiencing physically distressing symptoms (e.g., pain, shortness of } \\
\text { breath, nausea) }\end{array}$ & 3.00 & 4.00 & 3.25 & .50 \\
\hline Feeling that how I look to others has changed significantly & 1.00 & 2.00 & 1.25 & .50 \\
\hline Feeling depressed & 1.00 & 3.00 & 2.25 & .96 \\
\hline Feeling anxious & 2.00 & 3.00 & 2.25 & .50 \\
\hline Feeling & 1.00 & 2.00 & 1.75 & .50 \\
\hline Worrying about $r$ & 1.00 & 1.00 & 1.00 & .00 \\
\hline Not being able & 1.00 & 2.00 & 1.50 & .58 \\
\hline Not being able to continue with my usuz & 1.00 & 2.00 & 1.75 & .50 \\
\hline Feeling like I am no longer who I was & 1.00 & 2.00 & 1.25 & .50 \\
\hline Not $f$ & 1.00 & 1.00 & 1.00 & .00 \\
\hline Not being able & 1.00 & 1.00 & 1.00 & .00 \\
\hline Feeling that life no longer has meaning & 1.00 & 2.00 & 1.25 & .50 \\
\hline $\begin{array}{l}\text { Feeling that I am not making a meaningful and/or lasting contribution in } \\
\text { my life }\end{array}$ & 1.00 & 2.00 & 1.50 & .58 \\
\hline $\begin{array}{l}\text { Feeling that I have "unfinished business" (e.g., things that I have yet to } \\
\text { say or do, or that feel incomplete) }\end{array}$ & 1.00 & 1.00 & 1.00 & .00 \\
\hline Concern that my spiritual life is not me & 1.00 & 2.00 & 1.50 & .58 \\
\hline Feeling & 1.00 & 1.00 & 1.00 & .00 \\
\hline Feeling that I don't have & 1.00 & 1.00 & 1.00 & .00 \\
\hline Feeling that my illness and care needs have rec & 1.00 & 1.00 & 1.00 & .00 \\
\hline Not feeling supported by my community of friends and family & 1.00 & 1.00 & 1.00 & .00 \\
\hline Not feeling supported by my health care providers & 1.00 & 1.00 & 1.00 & .00 \\
\hline $\begin{array}{l}\text { Feeling like I am no longer able to mentally "fight" the challenges of my } \\
\text { illness }\end{array}$ & 1.00 & 3.00 & 1.50 & 1.00 \\
\hline Not being able to accept the way & 1.00 & 1.00 & 1.00 & .00 \\
\hline Not being treated with respect or understanding by others & 1.00 & 1.00 & 1.00 & .00 \\
\hline
\end{tabular}

